\title{
Morphological and biochemical changes in the pancreas associated with acute systemic hypoxia
}

\author{
Fumiya Morioka ${ }^{1}$ D $\cdot$ Naoto Tani $^{1,2} \cdot$ Tomoya Ikeda $^{1,2} \cdot$ Tatsuya Hirokawa $^{1,2} \cdot$ Kei Ikeda $^{1} \cdot$ Alissa Shida $^{1} \cdot$ Yayoi Aoki $^{1} \cdot$ \\ Takaki Ishikawa ${ }^{1,2}$
}

Received: 1 October 2020 / Accepted: 30 December 2020 / Published online: 2 February 2021

(c) The Author(s) 2021

\begin{abstract}
This study aimed to investigate the changes associated with acute systemic hypoxia in the endocrine system, particularly in pancreatic tissues. The investigation was based on macroscopic, pathohistological, biochemical, and molecular biological findings in cell lines and human cadavers. The results showed that cases of death due to asphyxia more frequently showed severe subcapsular/interstitial hemorrhage versus the other causes of death. Histological examination showed that asphyxia cases were associated with severe morphological changes. Although measured insulin levels in the asphyxia were higher compared to other causes of death, no differences were noted for the glucagon and amylase levels with regard to the cause of death. Increased blood insulin levels were not associated with macro- and micromorphological changes, and did not show any association with glucose or cortisol levels. The experiment conducted under hypoxic conditions in cultured cells demonstrated that insulin mRNA expression and insulin protein levels peaked at $10 \mathrm{~min}$ after hypoxia exposure. However, there were no changes in either the amylase mRNA or protein levels. Corticosterone level peaked at 120 min after exposure to hypoxic conditions. Overall, acute systemic hypoxic conditions can directly affect the mechanisms involved in pancreatic insulin secretion.
\end{abstract}

Keywords Hypoxia $\cdot$ Insulin $\cdot$ Glucose $\cdot$ Cortisol $\cdot$ Cell culture

\section{Introduction}

Acute systemic hypoxia caused by asphyxia and acute circulatory failure due to cardiac disease substantially impacts various organs. Endocrine organs have an extensive vasculature making them particularly sensitive to systemic hypoxia [1-3]. Hypoxic conditions can have both morphological and functional impacts on the endocrine glands and hormone production $[4,5]$. While studies have evaluated pathologies induced by acute systemic hypoxia, little research has addressed hypoxia's effects on the endocrine system $[6,7]$.

Fumiya Morioka

fmorioka@med.osaka-cu.ac.jp

1 Department of Legal Medicine, Osaka City University Medical School, 1-4-3 Asahi-machi, Abeno, Osaka 545-8585, Japan

2 Forensic Autopsy Section, Medico-Legal Consultation and Postmortem Investigation Support Center (MLCPI-SC), Osaka, Japan
As a result, we have conducted several studies designed to investigate endocrine system abnormalities that occur due to systemic hypoxia [8-10]. In an earlier report we found blood and cerebrospinal fluid (CSF) to have increased levels of triiodothyronine (T3) and thyroxine (T4). Thyroid gland secretions were high during acute hypoxic/ischemic conditions, regardless of any mechanical stimuli such as cervical compression [8]. We also found an increase in the pituitary gland blood-to-CSF transport of prolactin (PRL). This information led us to conclude that the pituitary gland receives neural stimulation under hypoxic conditions [9]. After looking at these results, we investigated exocrine and endocrine functions of the pancreas after acute hypoxia treatment and found very little literature. Our group went on to look at how the pancreas reacts to systemic hypoxic conditions. In this case we observed that subcapsular/interstitial hemorrhage occurs and serum amylase levels tend to be higher than the clinical reference range; which did not differ from levels seen in other causes of death [10]. This study investigated changes in the pancreas caused by acute systemic hypoxia with a particular focus on the effects on the endocrine cells 
in the human pancreas. We used cells from human autopsy cases where the body experienced acute systemic hypoxia as the cause of death. We also used cultured cells to conduct experiments during hypoxic conditions to further investigate the autopsy results.

\section{Materials and methods}

\section{Autopsy materials}

We examined a total of 94 serial forensic autopsy cases (66 males and 28 females: median age at death was 62 years) within $72 \mathrm{~h}$ postmortem. The inclusion criteria were cases where witnesses provided well-established circumstantial evidence confirming the injury/cause of death, and where the time of death was well defined [11]. A complete autopsy which included macromorphological, micropathological, toxicological, and postmortem radiographic examinations identified the following causes of death: asphyxia (systemic hypoxia disorder), sharp instrument injury (hemorrhagic shock), blunt injury (head injury and non-head injury), fire fatality (burn and carbon monoxide intoxication), drowning (alveolus injury), and acute cardiac death (cardiac failure) (Table 1). Patients with diabetes mellitus and liver cirrhosis were excluded from this study, as well as subjects with hyperthermia (heat stroke), crush syndrome, and intoxication due to the effect hemolysis may have on insulin concentrations $[12,13]$.

\section{Macropathological findings}

During the autopsy we determined pancreatic subcapsular/ interstitial hemorrhage frequency in accordance with the cause of death. Macroscopic pancreatic subcapsular/interstitial hemorrhage was scored according to the range and degree of bleeding as follows: 0 , no hemorrhage; 1 , local (slight) hemorrhage; 2, moderate hemorrhage; 3 , diffuse (severe) hemorrhage.

\section{Micropathological and immunohistochemical analyses}

Serial pancreatic specimens were used for hematoxylin-eosin staining. Scoring of the microscopic pancreatic tissue pattern changes across five random pancreatic tissues were based on three degrees of severity that included: nonemild type, scattering type, and diffuse type.

Pancreas hemorrhagic samples due to sharp instrument injury were collected and maintained at room temperature (postmortem period of about $24 \mathrm{~h}$ ) and then compared with the subsequent postmortem morphological changes. Histopathological findings were confirmed for each of the observation points ( 0 h, 12 h, 24 h, 2 days, 3 days, 4 days), respectively.

For the immunohistochemical analyses, the specimen was incubated overnight with insulin rabbit polyclonal antibodies (15848-1-AP; Proteintech, Rosemont, IL, USA) [14, 15] and glucagon (15954-1-AP; Proteintech) [15, 16] at room temperature. The total number of cells in the islets of Langerhans was counted for each specimen under $200 \times$ magnification, as well

Table 1 Case profile

\begin{tabular}{|c|c|c|c|c|c|c|}
\hline Cause of death & $n$ & Male/female & $\begin{array}{l}\text { Age } \\
(y) \\
\text { (median) }\end{array}$ & $\begin{array}{l}\text { Emergency medi- } \\
\text { cal care }\end{array}$ & $\begin{array}{l}\text { Survival period } \\
\text { (h) }\end{array}$ & $\begin{array}{l}\text { Postmortem period } \\
\text { (h) (median) }\end{array}$ \\
\hline Asphyxia & 22 & $14 / 8$ & $6-87(50.5)$ & 0 & $<0.5$ & $6-60(30)$ \\
\hline Blunt injury & 15 & $12 / 3$ & $30-84(57)$ & 0 & $<0.5$ & $6-48(24)$ \\
\hline Head injury & 6 & $5 / 1$ & $32-83(55.5)$ & 0 & $<0.5$ & $6-36(19)$ \\
\hline Non-head injury & 9 & $7 / 2$ & $30-84(57)$ & 0 & $<0.5$ & $12-48(20)$ \\
\hline Sharp instrument injury & 11 & $9 / 2$ & $22-75(57)$ & 0 & $<0.5$ & $6-60(18)$ \\
\hline Fire fatality & 23 & $16 / 7$ & $33-91(77)$ & 0 & $<0.5$ & $6-60(29)$ \\
\hline $\mathrm{CO}-\mathrm{Hb}<30 \%$ & 12 & $8 / 4$ & $33-91(75.5)$ & 0 & $<0.5$ & $6-60(31)$ \\
\hline $\mathrm{CO}-\mathrm{Hb} 30-60 \%$ & 6 & $5 / 1$ & $41-85(81)$ & 0 & $<0.5$ & $12-48(24)$ \\
\hline $\mathrm{CO}-\mathrm{Hb}>60 \%$ & 5 & $3 / 2$ & $43-87(65)$ & 0 & $<0.5$ & $24-60(25)$ \\
\hline Drowning & 11 & $3 / 8$ & $30-96(65)$ & 0 & $<0.5$ & $6-60(31)$ \\
\hline Acute cardiac death & 12 & $12 / 0$ & $16-83(63)$ & 0 & $<0.5$ & $12-60(30)$ \\
\hline Total & 94 & $66 / 28$ & $6-96(62)$ & 0 & $<0.5$ & $6-60(30)$ \\
\hline
\end{tabular}

$\mathrm{CO}-\mathrm{Hb}$ carbon monoxide hemoglobin 
as the number of insulin- and glucagon-positive cells in comparison to the total number of Langerhans cells.

\section{Biochemical analyses}

\section{Measurement of blood insulin, glucagon, and amylase concentrations}

Serum insulin concentrations were measured by a chemiluminescent enzyme immunoassay [17-19] using a fully automated chemiluminescent enzyme immunity measurement system (Lumipulse L2400: Fujirebio Inc., Tokyo, Japan). After aseptically collecting blood samples from the right heart chambers, all samples were immediately centrifuged to separate the sera. All measurements used the clinical serum insulin reference range $1.84-12.2 \mu \mathrm{IU} / \mathrm{mL}$ [20].

Serum glucagon concentrations were measured by radioimmunoassay (RIA) [21, 22] using a gamma counter (ARC8010, Hitachi, Ltd., Tokyo, Japan) and the Glucagon RIA "SML" (Euro-Diagnostica AB, Denis Pharma K.K., Tokyo, Japan), a glucagon measurement kit for plasma. This kit is based on the radioimmunoassay principle that uses a double antibody technique for determining the bound/free separation. For this measurement we used the clinical serum glucagon reference range of 70-174 $\mathrm{pg} / \mathrm{mL}$ [23].

In some cases, serum amylase concentrations were spectrophotometrically measured (JCA-BM8000: JEOL Inc., Tokyo, Japan) [24]. For this measurement, the clinical serum amylase reference range used was 37-125 U/L.

\section{Method and apparatus for measuring blood glucose and cortisol concentrations}

Blood glucose was measured using the hexokinase UV method [25-27]. Measurements were carried out using an automatic analysis device (JCA-BM6070, JEOL, Tokyo, Japan) and SHIKA liquids GLU J (Kanto Kagaku, Tokyo, Japan) as the reagent. The sample consisted of $0.5 \mathrm{~mL}$ of serum from the right heart using a standard measurement method with a clinical serum glucose concentration reference range of $70-109 \mathrm{mg} / \mathrm{dL}[28,29]$.

Right heart serum cortisol levels were measured using a competitive fluorescent enzyme immunoassay on the AIA3601 analyzer (Tosoh Bioscience $\mathrm{GmbH}$, Griesheim, Germany) [30, 31]. The lower and upper reported values for the cortisol assays were 0.2 and $60 \mu \mathrm{g} / \mathrm{dL}$, respectively.

\section{Cell culture under hypoxic conditions}

\section{Insulin- and amylase-secreting cell line}

This study used the BRIN-BD11 cell line, an insulinsecreting hybrid cell line formed by electrofusion between a primary culture of NEDH rat pancreatic islets and RINm5F (a cell line derived from a NEDH rat insulinoma). BRINBD11 has been shown to be tumorigenic when transplanted into SCID mouse hosts. Moreover, this cell line can be used for the study of pancreatic beta cell function [32]. The culture medium consisted of RPMI1640 supplemented with $10 \%$ fetal bovine serum (FBS). Cells were cultured in a humidified atmosphere of $4.7 \% \mathrm{CO}_{2}$ and $5 \% \mathrm{O}_{2}$ at $37{ }^{\circ} \mathrm{C}$. The cell count was measured using the Cell Counter model R1 (Olympus Optical Co., Ltd., Tokyo, Japan) following a trypan blue-exclusion test and then adjusted to $1.4 \times 10^{6}$ cells $/ \mathrm{mL}$ until $75 \mathrm{~min}$ of culture. Culture fluid insulin levels were subsequently measured via an enzyme-linked immunosorbent assay using a rat insulin measurement kit (Morinaga Institute of Biological Science Inc., Kanagawa, Japan). We also measured mRNA levels using reverse transcription-polymerase chain reaction (RT-PCR) after hypoxic exposure.

We added actinomycin D $(2 \mu \mathrm{g} / \mathrm{mL})$ to the BRIN-BD11 cells to block reproduction and transcription from DNA. Then we measured insulin, HIF1 $\alpha$, and vascular endothelial growth factor (VEGF) with and without actinomycin D.

AR42J cells are derived from a rat pancreatic external secretion adenocarcinoma [33]. We cultured the AR42J cells in a humidified atmosphere of $4.7 \% \mathrm{CO}_{2}$ and $5 \% \mathrm{O}_{2}$ at $37{ }^{\circ} \mathrm{C}$. Cell counts were done using the Cell Counter model R1 (Olympus Optical Co., Ltd., Tokyo, Japan), with the cells adjusted to $1.0 \times 10^{6}$ cells $/ \mathrm{mL}$ until $24 \mathrm{~h}$ of culture. Culture fluid amylase levels were also measured using a colorimetric analysis (SPOTCHEM D-Concept ${ }^{\mathrm{TM}}$, ARKRAY Inc., Kyoto, JAPAN) [34].

\section{Corticosterone-secreting Y-1 adrenal cell line}

Corticosterone-secreting Y-1 adrenal cells derived from mice were developed to verify whether these cells secrete hormones upon stimulation due to exposure to hypoxia. Mouse Y-1 adrenocortical tumor cells (ATCC, CCL-79) were established in a male mouse $[35,36]$. The culture medium consisted of a 1:1 ratio of DMEM-F12 and 15\% charcoal stripped FBS (Biological Industries, Cromwell, CT, USA) with $4 \mathrm{mM} \mathrm{L}$-glutamine, $50 \mathrm{U} / \mathrm{mL}$ penicillin and $50 \mu \mathrm{g} / \mathrm{mL}$ streptomycin. Initially, cells of both types were seeded and cultured at $37^{\circ} \mathrm{C}$. Growth was controlled at about $1 \times 10^{5}$ cells $/ \mathrm{cm}^{2}$ for $\mathrm{Y}-1$, with the cells allowed to proliferate until they covered the surface of the culture dish. After the Y-1 cells reached confluence, they were then transferred to $1 \% \mathrm{O}_{2}$ and maintained. The amount of corticosterone in the culture medium was measured at 10, 30, 60, 120, 240, 480, 720, 1440 (1 day), 2880 (2 days), and 4320 min (3 days). Corticosterone was measured using a mouse corticosterone assay kit (ELISA kit, No: \#501320, Cayman Chemical Company, Ann Arbor, MI, USA) [37, 38]. At the end of the experiment, adherent cells were dissociated 
from the surface using trypsin and then counted, hormone concentrations were then calculated using a correction formula in conjunction with the measured values. We measured HIF1 $\alpha$ (Sandwich ELISA kit, CBA-280, Cell Biolabs Inc., San Diego, CA, USA) [39, 40] and VEGF (ELISA kit, ab209882, Abcam, Tokyo, Japan) as the control [41].

\section{Quantitative reverse transcription-polymerase chain reaction of cultured cells}

Total RNA was isolated using Isogen reagent (Nippon Gene, Toyama, Japan) in accordance with the manufacturer's instructions. cDNA copies of the total RNA were synthesized using the High-Capacity RNA-to-cDNA Kit (Applied Biosystems, Foster City, CA, USA). The reaction mixture included $9 \mu \mathrm{L}$ samples of total RNA, $10.0 \mu \mathrm{L}$ of $2 \times \mathrm{RT}$ buffer, and $1.0 \mu \mathrm{L}$ of $20 \times \mathrm{RT}$ enzyme mix. Conditions for the reverse transcription were as follows: $37^{\circ} \mathrm{C}$ for $60 \mathrm{~min}$ and then $95^{\circ} \mathrm{C}$ for $5 \mathrm{~min}$. A total of $20.0 \mu \mathrm{L}$ of reaction mixture containing $10.0 \mu \mathrm{L}$ of TaqMan gene expression master mix $(2 \times), 1.0 \mu \mathrm{L}$ of TaqMan gene expression assay $(20 \times), 4 \mu \mathrm{L}$ of cDNA, and $5 \mu \mathrm{L}$ of $\mathrm{H}_{2} \mathrm{O}$ were added to each well of a Fast 96-Well Reaction Plate $(0.1 \mathrm{~mL}$, Applied Biosystems). Quantitative RT-PCR was performed using primers for Insulin 1 (Ins1: TaqMan assay ID: Rn0212433_g1), Insulin 2 (Ins2: TaqMan assay ID: Rn01774648_g1), and amylase (Amy 2a3: TaqMan assay ID: Rn00821330-g1) on a StepOnePlus real-time PCR system (Applied Biosystems). The threshold cycle was calculated automatically using the instrument software, with a threshold value of 0.2 . For this study, $\beta$-actin (TaqMan assay ID: Rn00667869_m1) was used as the endogenous reference gene. TaqMan Gene Expression Assays were purchased from Applied Biosystems and tested in accordance with the manufacturer's protocol [42].

\section{Structural imaging using a transmission electron microscope}

Cultured endocrine cells (BRIN-BD11) and acinar cells (AR42J) of the pancreas were collected under conditions of hypoxia. The cells were prefixed using $2.5 \%$ glutaraldehyde and $2 \%$ paraformaldehyde buffered with $0.1 \mathrm{M}$ phosphate buffer (pH 7.4) at $4{ }^{\circ} \mathrm{C}$ overnight and then fixed with $1 \%$ osmium tetroxide buffered with $0.1 \mathrm{M}$ phosphate buffer for $2.5 \mathrm{~h}$ at $4{ }^{\circ} \mathrm{C}$. Ultrathin sections were prepared from resin blocks using a diamond knife on an ultramicrotome (Ultracut UCT, Leica, Vienna, Austria). Sections were stained with 5\% uranyl acetate in 50\% ethanol for 20 min and Reynolds' lead citrate for $3 \mathrm{~min}$. Stained sections were then analyzed using TEM (H-7500, Hitachi) [43].

\section{Statistical analyses}

We used Fisher's exact test to compare the parameters of pancreatic macromorphological findings between the causes of death. $p$ values for the tests were adjusted in accordance with the Benjamini-Hochberg false discovery rate method. The same methodology was used to compare the micro pancreatic tissue findings. Spearman's rank correlation coefficient was used to examine the correlation between the two continuous parameters. The Steel-Dwass test was used for multiple comparisons among the groups. In addition, the utility of the serum insulin and glucagon levels for differentiating between death due to asphyxia and other causes was evaluated using receiver operating characteristic (ROC) curves and the areas under the curves. Youden's index (sensitivity + specificity -1 ) was used to determine the best cutoff values. Results are presented as medians and interquartile ranges, unless otherwise stated. A $p$ value of $<0.05$ was considered significant. All statistical procedures, including the ROC analyses, were performed using SPSS 9.0 (SPSS Inc., Chicago, IL, USA).

\section{Results}

\section{Macroscopic pancreatic subcapsular/interstitial hemorrhage ratio and histopathological pancreatic tissue pattern changes associated with the cause of death}

Macromorphological findings indicated that there were pancreatic subcapsular/interstitial hemorrhages present without any observed injury (Fig. 1a). Histopathological findings showed there were three patterns of pancreatic tissue damage, which included both the exocrine and endocrine glands. Figure $1 \mathrm{~b}$ shows each of the histological findings for the asphyxia cases [(i) none to mild type, (ii) scattering type, (iii) diffuse type].

In contrast, when changes in the pancreatic tissue based on the postmortem period were evaluated, there were no differences observed after $12 \mathrm{~h}$. The micromorphological changes appeared conspicuously after 2 days of the postmortem period, with pancreatic cells diffusely falling off. Two days posthumously, the histologic form was no longer maintained (Fig. 2a-f). Individuals who died due to asphyxia (77.3\%) had a higher incidence of macroscopic pancreatic subcapsular/interstitial hemorrhage as compared to those who died due to other causes (13.0-53.3\%, mean 27.9\%) with the exception for drowning (72.7\%) (Fig. 3a and Table 2). Those who died due to asphyxia had macroscopic pancreatic subcapsular/interstitial hemorrhage score classified as severe (score of 3) (Fig. 3a and Table 2). There was no relationship found between the macroscopic pancreatic 


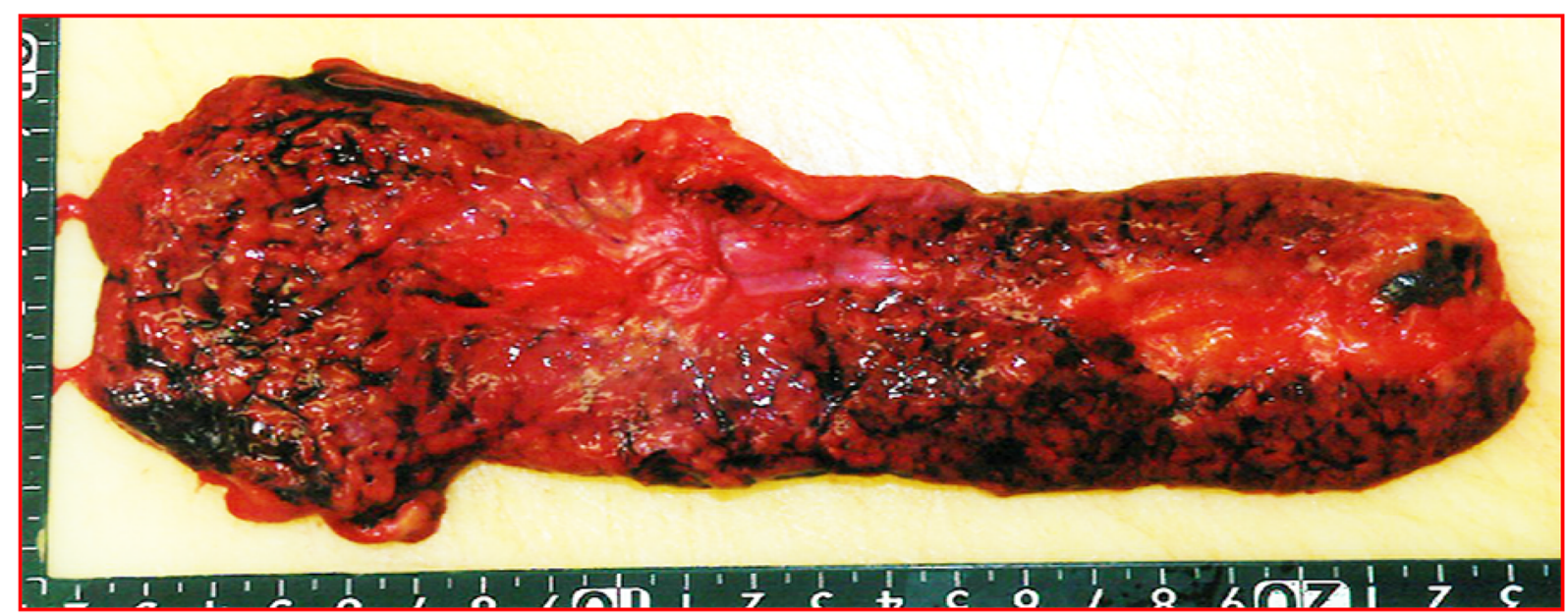

$\mathbf{a}$

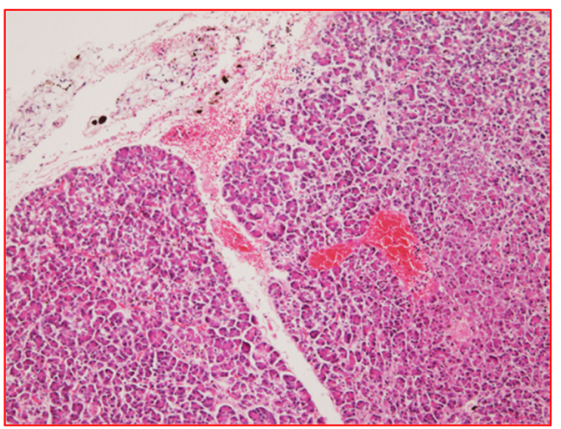

(i) None-mild type

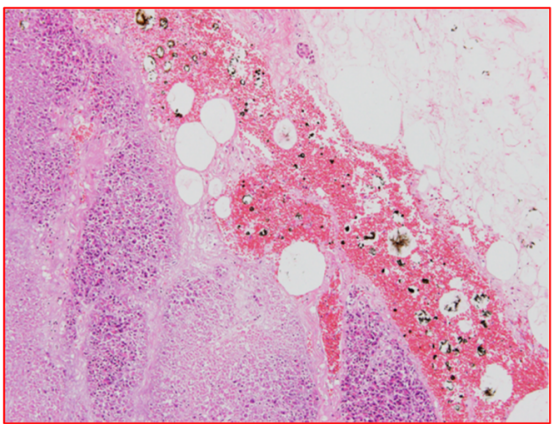

(ii) Scattering type

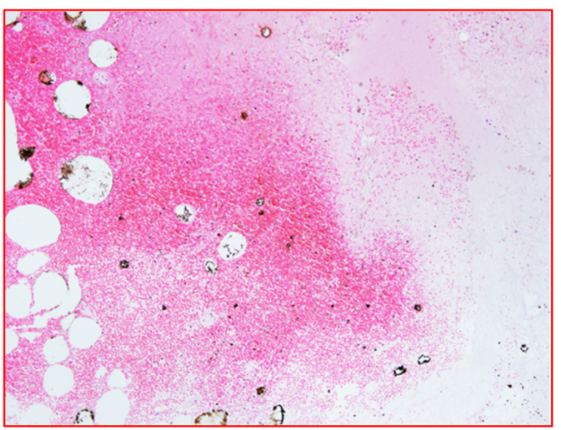

(iii) Diffuse type

b

Fig. 1 a Macromorphological findings showing pancreatic subcapsular/interstitial hemorrhage without parenchymal injury. b Panels (i)(iii) show each of the histological findings (a: none to mild type, b: scattering type, c: diffuse type). Figure indicates (i) male in his $50 \mathrm{~s}$,

subcapsular/interstitial hemorrhage score and the postmortem period (Fig. 3b). Statistical evaluation demonstrated that the moderate or severe hemorrhage cases were higher for asphyxia as compared to sharp instrument injury and fire fatality ( $p<0.05, p<0.001)$ (Fig. 3a).

Histopathological analyses demonstrated that diffuse type of pancreatic tissue damage changes, including acinar and islet cells, were found more often for asphyxia (90.9\%) as compared to those who died from other causes (45.5-60.0\%, mean $53.3 \%$ ), excluding acute cardiac death (Fig. 4a and Table 2). No significant differences were noted between the pancreatic micromorphological tissue changes and the postmortem period (Fig. 4b).

\section{Immunohistochemical analysis}

The islets of Langerhans exhibited staining for both insulin and glucagon (Fig. 5a, b). There were no significant asphyxia, postmortem period $18 \mathrm{~h}$; (ii) female in her $80 \mathrm{~s}$, fire fatality, postmortem period $30 \mathrm{~h}$; (iii) male in his $30 \mathrm{~s}$, asphyxia, postmortem period $20 \mathrm{~h}$

differences in the percentages of the insulin- and glucagonpositive cells observed among the causes of death in the islets of Langerhans (Fig. 5c, d, and Table 2).

\section{Postmortem serum insulin, glucagon, and amylase levels}

Serum insulin levels were slightly negatively correlated with the subject's age $(r=-0.324, p<0.01)$, but not with sex or the postmortem period. Those who died due to asphyxia had higher serum insulin levels (median, $5.0 \mu \mathrm{IU} / \mathrm{mL}$ ) as compared to those who died due to other causes (median, $2.1 \mu \mathrm{IU} / \mathrm{mL}$ ). A cut-off insulin level of $5.8 \mu \mathrm{IU} / \mathrm{mL}$ (sensitivity 0.861 ; specificity 0.500 ) was identified for predicting asphyxia (Fig. 6a and Table 3).

Serum glucagon levels were found to have no relationship with the age, sex, and postmortem period. For all causes of death, the glucagon level was higher than the upper clinical 


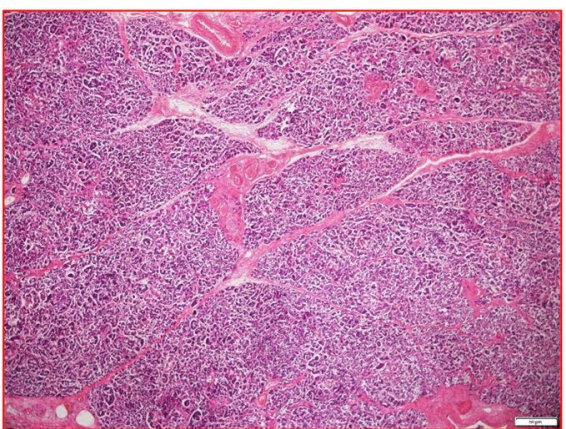

a 0 hours after sampling

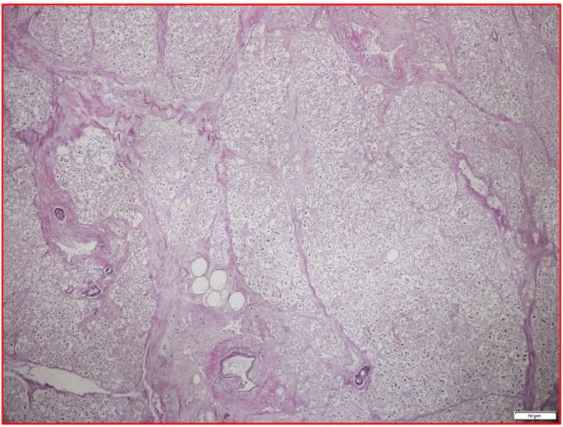

d 2 days after sampling

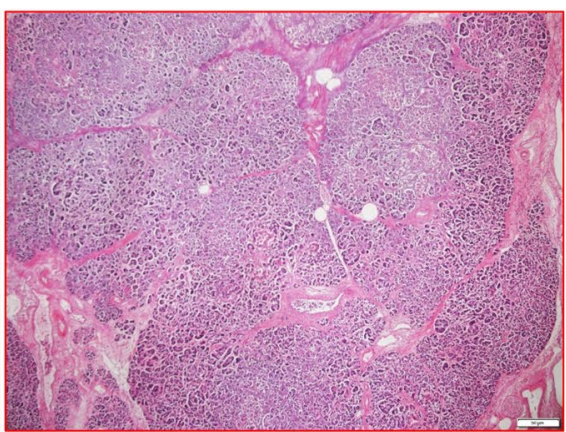

b 12 hours after sampling

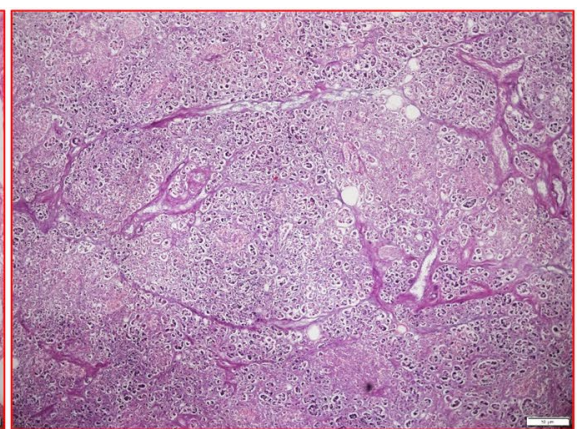

c 1 day after sampling

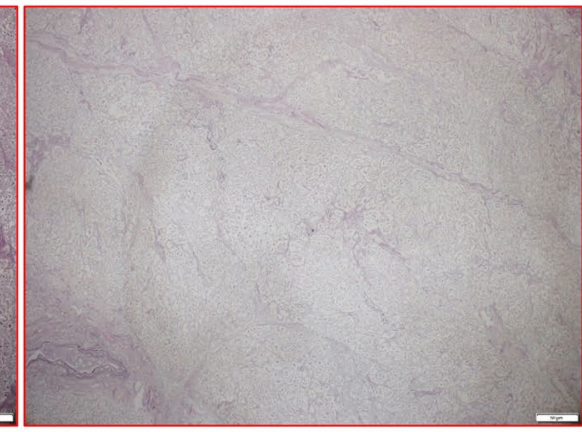

e 3 days after sampling

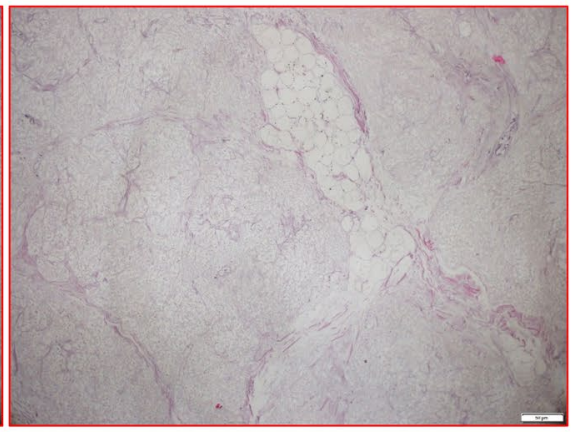

f 4 days after sampling

Fig. 2 The figure shows the changes observed for the elapsed times for each of the extracted pancreas samples at autopsy. a $0 \mathrm{~h}$ after sampling, $\mathbf{b}$ $12 \mathrm{~h}$ after sampling, $\mathbf{c} 1$ day after sampling, $\mathbf{d} 2$ days after sampling, $\mathbf{e} 3$ days after sampling, $\mathbf{f} 4$ days after sampling

reference range. However, among all causes of death, there was no significant difference noted in the serum glucagon levels (Fig. 6b and Table 3).

There was also no relationship found between the serum amylase levels and the age, sex, and postmortem period. For all causes of death, amylase levels were approximately within the clinical reference range. There were no groups with conspicuously high amylase levels (Fig. 6c and Table 3).

The macromorphological hemorrhage level and micropathological pattern changes were found to have no relationship with either the serum insulin or glucagon levels (Fig. 7a-d). The macromorphological severe hemorrhage cases tended to exhibit low serum insulin levels even though there was no statistic significant difference observed when the asphyxia cases were compared (Fig. 7b).

\section{Postmortem serum cortisol and glucose levels}

There were no significant differences observed in the serum cortisol levels among the causes of death (Fig. $8 \mathrm{a}$ and Table 3). While the glucose level tended to be high for asphyxia (7.0-830.0 mg/dL, median $302.5 \mathrm{mg} / \mathrm{dL}$ ), drowning (1.0-693.0 mg/dL, median $273.0 \mathrm{mg} / \mathrm{dL})$, and acute cardiac death (1.0-546.0 mg/dL, median $248.5 \mathrm{mg} / \mathrm{dL})$, there was no statistically significant difference noted for all causes of death (1.0-830.0 mg/dL, median $217.5 \mathrm{mg} / \mathrm{dL}$ ) (Fig. $8 \mathrm{~b}$ and Table 3).

The serum insulin levels in the present study did not exhibit any correlation with serum cortisol or glucose (Fig. 8c, d).

\section{Insulin concentrations and insulin mRNA levels in the conditioned medium BRIN-BD11 cultured under hypoxic conditions}

BRIN-BD11 cells showed increased insulin levels following incubation for $10 \mathrm{~min}$ under 5\% hypoxic conditions (Fig. 9a and Table 4). However, the insulin levels decreased gradually after $15 \mathrm{~min}$.

Evaluation of the insulin mRNA expression demonstrated that the Ins 1 expression increased after incubation for 10 min under hypoxic conditions in conjunction with the insulin levels in the culture medium (Fig. 9b and Table 4). Ins 2 expression exhibited a high level within $10 \mathrm{~min}$, but the levels and variations were both low as compared to that observed for Ins1 under hypoxic conditions (Fig. 9c and Table 4). 


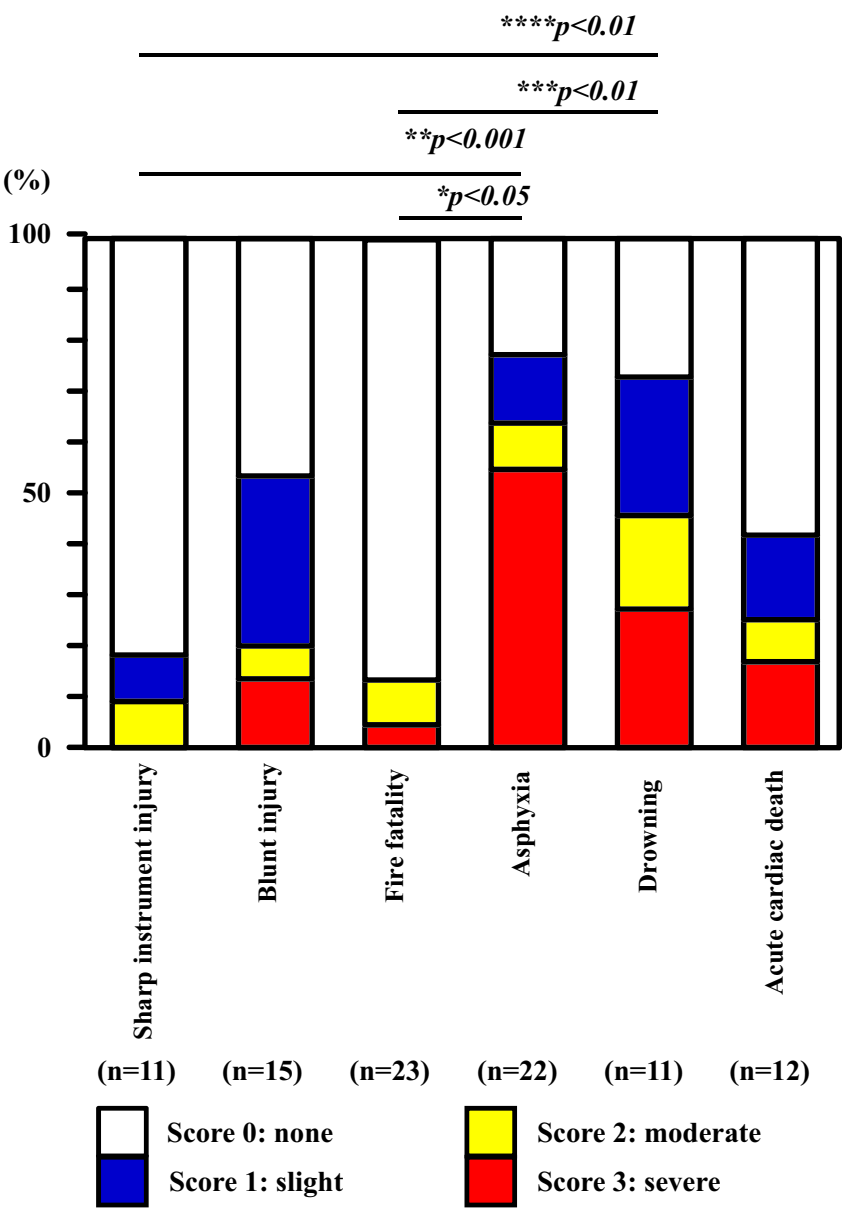

Fig. 3 a Range and/or degree of macroscopic pancreatic subcapsular/ interstitial hemorrhage according to the cause of death. Moderate to high scores (score of 2 and 3 ) were observed in the asphyxia cases. b Graph showing a ratio of macroscopic pancreatic tissue hemorrhage

After adding actinomycin D to the BRIN-BD11 cells, we measured the insulin concentrations. Results showed that the insulin concentrations were all at low levels including the actinomycin $\mathrm{D}$ in comparison with excluding the actinomycin D (Fig. 9d and Table 4).

\section{HIF1a and VEGF concentrations in the conditioned medium BRIN-BD11 when cultured under hypoxic conditions}

HIF1 $\alpha$ and VEGF were used as control markers for cellular function during hypoxic conditions in BRIN-BD11 cells. HIF1 $\alpha$ levels increased and reached maximum secretion at $30 \mathrm{~min}(2.97-7.33 \mathrm{ng} / \mathrm{mL}$, median $4.39 \mathrm{ng} / \mathrm{mL})$ (Fig. 10a and Table 4). VEGF levels increased from $15 \mathrm{~min}$ (1247.0-1694.0 pg/mL, median $1336 \mathrm{pg} / \mathrm{mL}$ ) until $30 \mathrm{~min}$

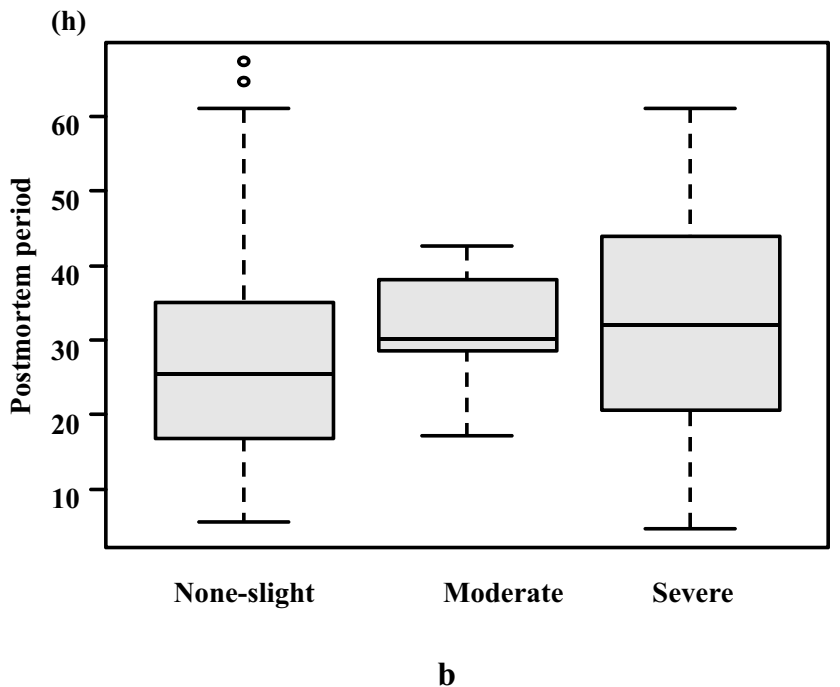

levels in the postmortem period. There was no significant relationship observed between the postmortem period and pancreatic hemorrhage degree $(p>0.05)$

(1138.0-1684.0 pg/mL, median $1401 \mathrm{pg} / \mathrm{mL}$ ), with the maximum reached at $60 \mathrm{~min}$ (Fig. 10b and Table 4).

After the addition of actinomycin D during hypoxia, the HIF1 $\alpha$ (Fig. 10c and Table 4) and VEFG (Fig. 10d and Table 4) levels exhibited a smaller and less significant difference for the measurements taken after initial administration (Table 4).

\section{Amylase concentrations and amylase mRNA levels in the conditioned medium AR42J cultured under hypoxic conditions}

The AR42J cells exhibited no increase in amylase levels following a $0-60 \mathrm{~min}$ incubation under $5 \%$ hypoxic conditions in the conditioned medium (Fig. 11a and Table 5), and the mRNA amylase level was similar to the amylase concentration at each of the time points (Fig. 11b and Table 5). 
Table 2 Results of the macromorphological, micropathological, and immunohistochemical examinations in the pancreas

\begin{tabular}{|c|c|c|c|c|c|}
\hline \multirow[t]{2}{*}{ Cause of death } & \multirow{2}{*}{$\begin{array}{l}\text { Number } \\
(n)\end{array}$} & \multirow{2}{*}{$\begin{array}{l}\text { Macromorphological interstitial/ } \\
\text { subcapsular hemorrhage (None- } \\
\text { slight/moderate/severe) } \\
\text { (Number: } n \text { ) }\end{array}$} & \multirow{2}{*}{$\begin{array}{l}\text { Micropathological tissue } \\
\text { changes (None-mild/scattering/ } \\
\text { diffuse) } \\
\text { (Number: } n \text { ) }\end{array}$} & \multicolumn{2}{|c|}{ Immunohistochemical staining } \\
\hline & & & & $\begin{array}{l}\text { Insulin } \\
(\% ; \text { median })\end{array}$ & $\begin{array}{l}\text { Glucagon } \\
(\% ; \text { median })\end{array}$ \\
\hline Asphyxia & 22 & $8 / 2 / 12$ & $2 / 5 / 15$ & $41.6-80.8(61.4)$ & $15.5-38.6(28.3)$ \\
\hline Blunt injury & 15 & $12 / 1 / 2$ & $6 / 3 / 6$ & $44.7-69.5(60.7)$ & $14.7-39.4(27.1)$ \\
\hline Head injury & 6 & $5 / 1 / 0$ & $2 / 1 / 3$ & $44.7-65.3(60.8)$ & $22.8-35.7(30.1)$ \\
\hline Non-head injury & 9 & $7 / 0 / 2$ & $4 / 2 / 3$ & $49.9-69.5(59.4)$ & $14.7-39.4(25.6)$ \\
\hline Sharp instrument injury & 11 & $10 / 1 / 0$ & $5 / 4 / 2$ & $34.7-77.4(58.8)$ & $17.8-46.7(32.1)$ \\
\hline Fire fatality & 23 & $20 / 2 / 1$ & $11 / 6 / 6$ & $39.0-70.9(55.1)$ & $13.9-70.5(26.2)$ \\
\hline $\mathrm{CO}-\mathrm{Hb}<30 \%$ & 12 & $11 / 1 / 0$ & $5 / 5 / 2$ & $39.0-70.5(53.8)$ & $15.0-70.5(25.7)$ \\
\hline $\mathrm{CO}-\mathrm{Hb} 30-60 \%$ & 6 & $5 / 1 / 0$ & $2 / 1 / 3$ & $48.2-70.9(60.6)$ & $13.9-32.9(23.2)$ \\
\hline $\mathrm{CO}-\mathrm{Hb}>60 \%$ & 5 & $4 / 0 / 1$ & $4 / 0 / 1$ & $43.5-62.4(54.6)$ & $22.0-36.6(27.7)$ \\
\hline Drowning & 11 & $6 / 2 / 3$ & $6 / 2 / 3$ & $45.8-70.6(59.5)$ & $17.4-48.2(30.6)$ \\
\hline Acute cardiac death & 12 & $9 / 1 / 2$ & $1 / 5 / 6$ & $38.6-74.7(63.4)$ & $15.6-54.3(35.3)$ \\
\hline Total & 94 & $65 / 9 / 20$ & $31 / 25 / 38$ & $34.7-80.8(59.4)$ & $13.9-70.5(28.9)$ \\
\hline
\end{tabular}

$\mathrm{CO}-\mathrm{Hb}$ carbon monoxide hemoglobin

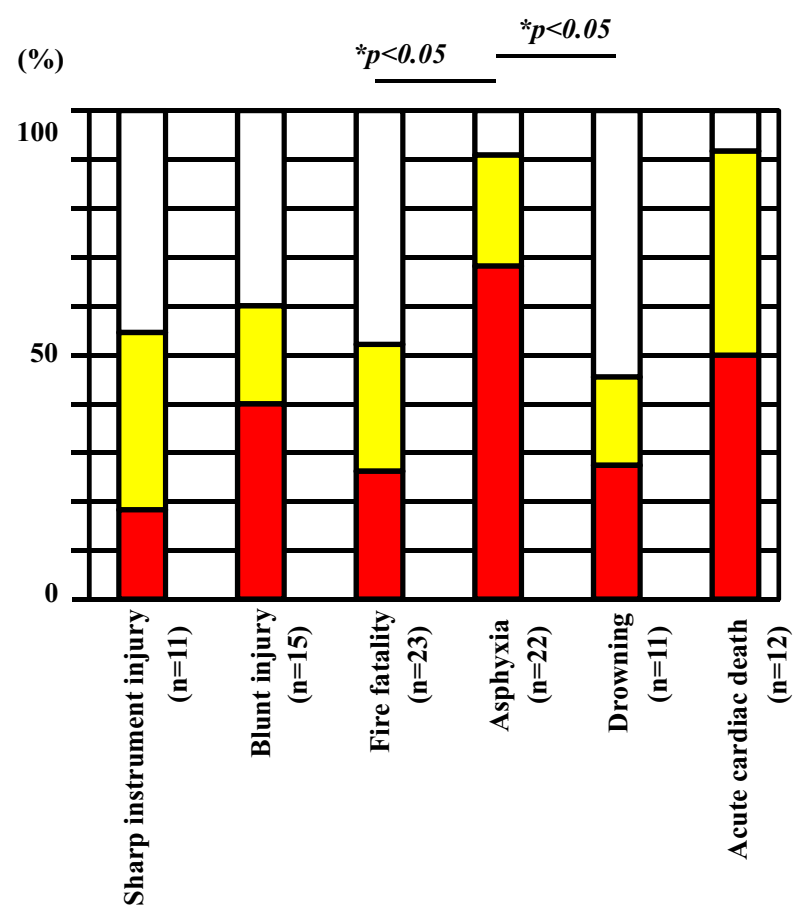

$\square$ None-mild type $\square$ Scattering type $\square$ Diffuse type

Microscopic pancreatic tissue pattern changes

a

Fig. 4 a Graph showing score ratios for microscopic pancreatic tissue pattern changes. Asphyxia cases exhibited a scattering and diffuse pattern (moderate to severe) as compared to the other causes of death. b Graph showing the ratio of the microscopic pancreatic tissue pat- (h)

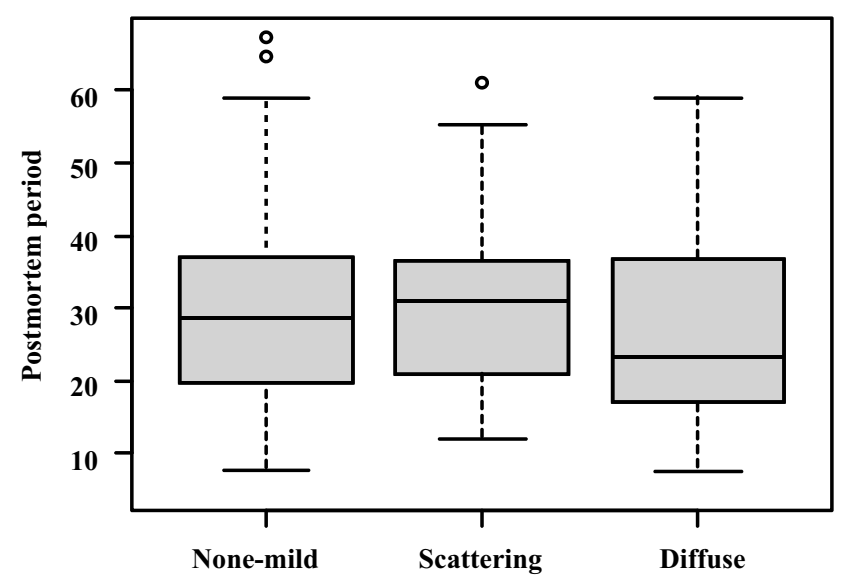

Microscopic pancreatic tissue pattern changes

b tern changes in the postmortem period. There was no significant relationship between the postmortem period and microscopic pancreatic tissue pattern changes $(p>0.05)$ 


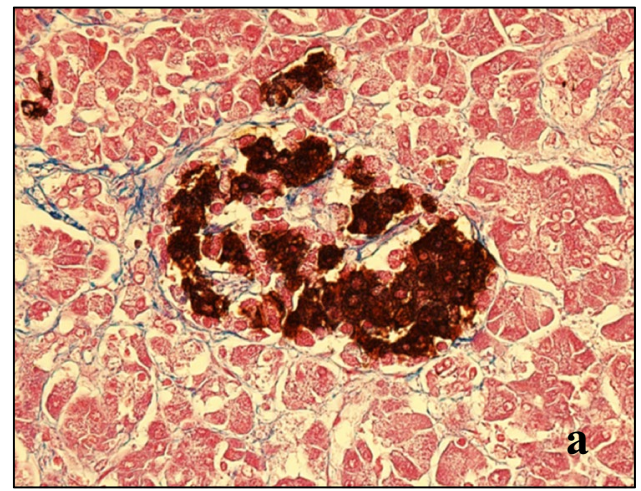

(\%)

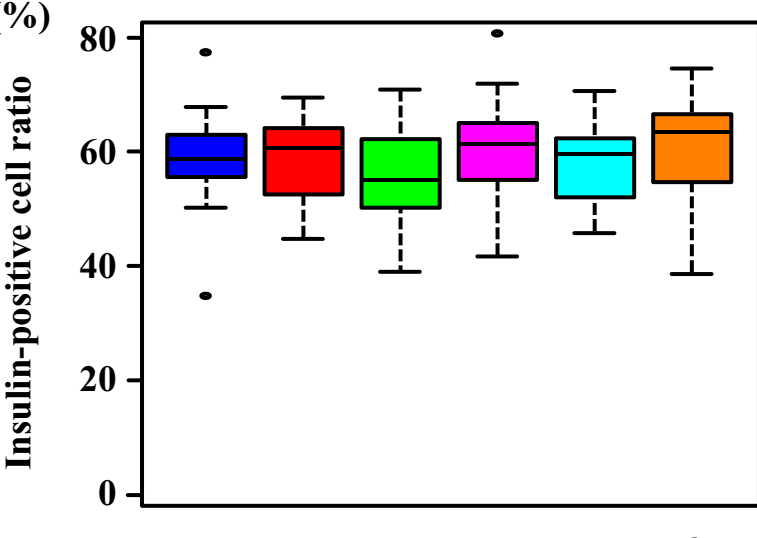

c
Sharp instrument injury

Blunt injury
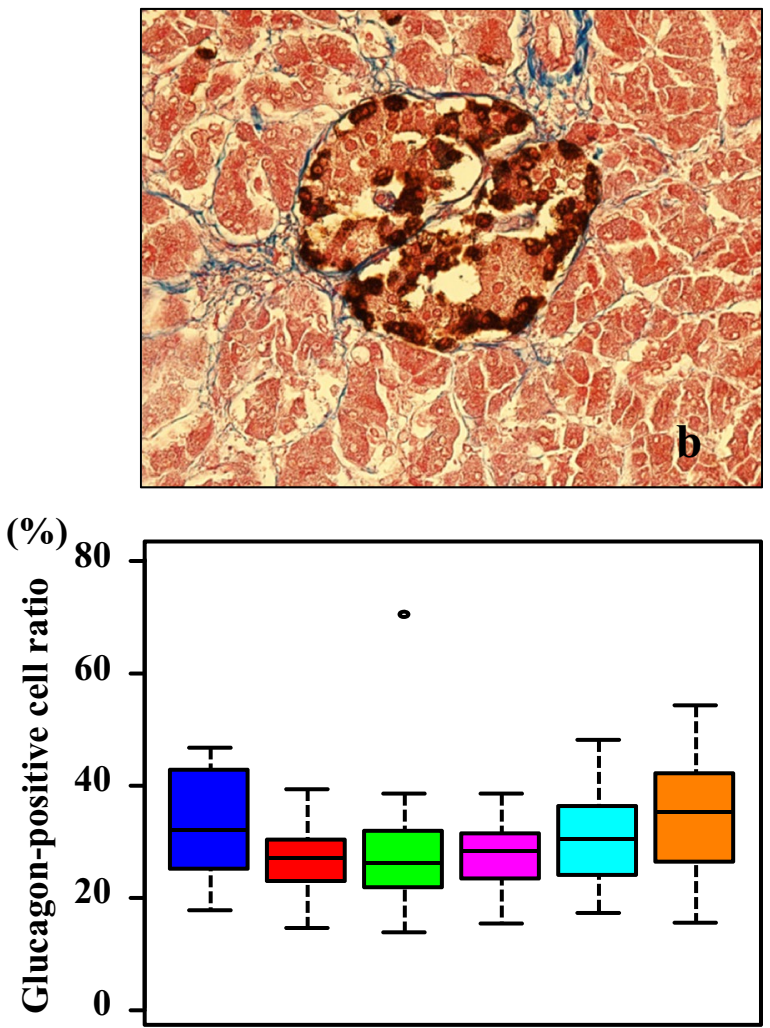

d
Fire fatality

Asphyxia
Drowning

\section{Acute cardiac death}

Fig. 5 The figure shows the insulin (a) and glucagon (b) immunostaining in the Langerhans cells of the pancreas. Immunohistochemical findings for the percentage of insulin-positive (c) and glucagon-positive (d) cells in the Langerhans cells. There were no significant differences for the percentage of insulin- or glucagon-positive cells found among all causes of death $(p>0.05)$

\section{Transmission electron microscope imaging in the BRIN-BD11 and AR42J cell culture model}

After culturing pancreatic internal secretion cells (BRINBD11) under hypoxia, changes at each time point were evaluated using an electron microscope. Results showed that the cell structure was maintained for approximately 10 min under conditions of hypoxia. However, mitochondrial swelling and nuclear structure collapse started to become apparent after approximately 15 min under hypoxia (Fig. 12a-f).

There were no changes in the cell organelles between the pancreatic external secretion cell line (AR42J) and the BRIN-BD11 cell line, with the exception of mitochondrial edema (Fig. 13a-f).

\section{Corticosterone, HIF1a, and VEGF concentrations in $\mathrm{Y}-1$ cells cultured under hypoxic conditions}

The corticosterone level continued to increase from $10 \mathrm{~min}$ (7.1-7.9 ng/mL, median: $7.4 \mathrm{ng} / \mathrm{mL}$ ) until it peaked at $120 \mathrm{~min}(79.7-88.6 \mathrm{ng} / \mathrm{mL}$, median $82.6 \mathrm{ng} / \mathrm{mL})$ during hypoxic conditions (Fig. 14a and Table 6). Levels of HIF1 $\alpha$ and VEGF were used as control markers for cellular function during hypoxic conditions in Y-1 cells. HIF1 $\alpha$ increased from $10 \mathrm{~min}(2.2-3.1 \mathrm{ng} / \mathrm{mL}$, median $2.6 \mathrm{ng} / \mathrm{mL})$ until it peaked at $60 \mathrm{~min}(50.6-54.4 \mathrm{ng} / \mathrm{mL}$, median $52.8 \mathrm{ng} / \mathrm{mL})$ (Fig. 14b and Table 6), and VEGF increased from $10 \mathrm{~min}$ $(10.8-12.8 \mathrm{ng} / \mathrm{mL}$, median $12.3 \mathrm{ng} / \mathrm{mL})$ until it peaked at $240 \mathrm{~min}(96.7-105.2 \mathrm{ng} / \mathrm{mL}$, median $98.5 \mathrm{ng} / \mathrm{mL}$ ) (Fig. 14c and Table 6). 


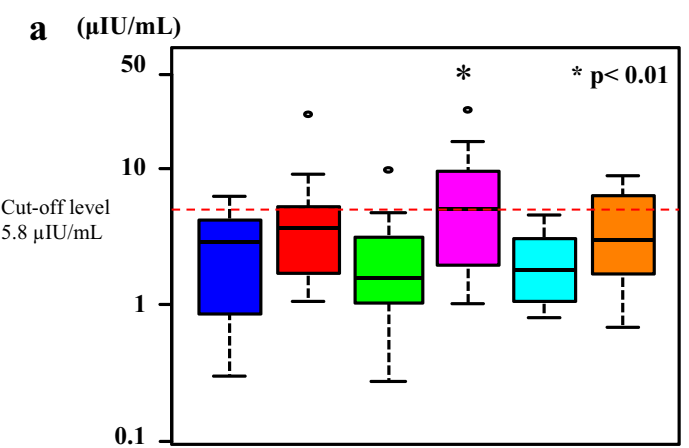

Insulin

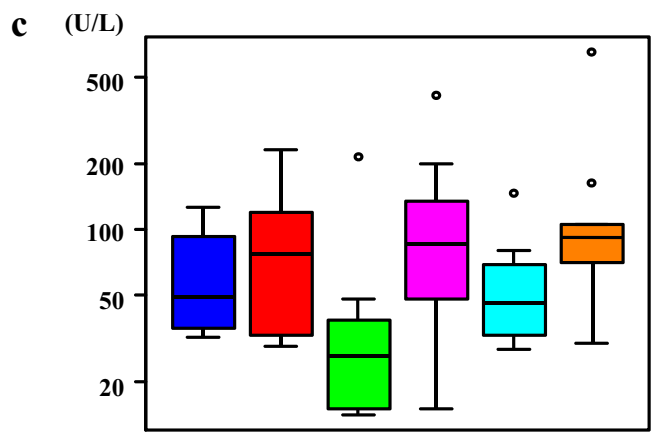

Pancreatic amylase

Fig. 6 Insulin (a), glucagon (b), and amylase (c) levels in the right heart blood according to the cause of death in the autopsy cases. Asphyxia cases show significantly higher blood insulin levels as com-

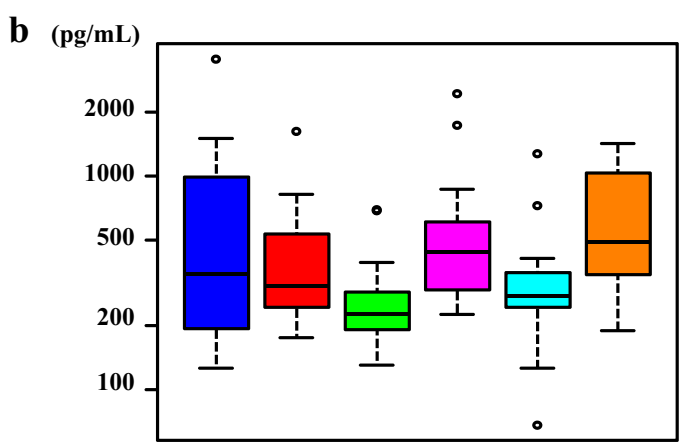

Glucagon

$\begin{array}{lll}\square & \text { Sharp instrument injury } & \text { Asphyxia } \\ \square & \text { Blunt injury } & \square \text { Drowning } \\ \square & \text { Fire fatality } & \text { Acute cardiac death }\end{array}$

pared to the other causes of death $(* p<0.01)$. No significant differences were observed for the blood glucagon and amylase levels in accordance with the cause of death $(p>0.05)$

Table 3 Blood insulin, glucagon, amylase, cortisol, and glucose levels in the right heart blood

\begin{tabular}{|c|c|c|c|c|c|c|}
\hline \multirow[t]{2}{*}{ Cause of death } & \multirow{2}{*}{$\begin{array}{l}\text { Number } \\
(n)\end{array}$} & \multicolumn{5}{|l|}{ Right heart blood } \\
\hline & & $\begin{array}{l}\text { Insulin }(\mu \mathrm{IU} / \mathrm{mL}) \\
\text { (median) }\end{array}$ & $\begin{array}{l}\text { Glucagon }(\mathrm{pg} / \mathrm{mL}) \\
\text { (median) }\end{array}$ & $\begin{array}{l}\text { Amylase (U/L) } \\
\text { (median) }\end{array}$ & $\begin{array}{l}\text { Cortisol }(\mu \mathrm{g} / \mathrm{dL}) \\
(\text { median) }\end{array}$ & $\begin{array}{l}\text { Glucose }(\mathrm{mg} / \mathrm{dL}) \\
\text { (median) }\end{array}$ \\
\hline Asphyxia & 22 & $1.0-26.4(5.0)$ & $224-2445(440)$ & $15-412(86)$ & $3.3-24.6(9.6)$ & $7-830(302.5)$ \\
\hline Blunt injury & 15 & $1.1-24.4(3.7)$ & $175-1630(305)$ & 29-231 (77) & $2.7-61.2(13.8)$ & $3-502(167)$ \\
\hline Head injury & 6 & $1.1-24.4(3.5)$ & $213-820(371)$ & $58-231(120)$ & $2.7-61.2(9.9)$ & $3-185(97)$ \\
\hline Non-head injury & 9 & $1.3-8.9(4.3)$ & $175-1630(305)$ & 29-135 (34) & $3.4-31.8(13.9)$ & $50-502(325)$ \\
\hline Sharp instrument injury & 11 & $0.3-6.2(2.9)$ & $126-3550(350)$ & $32-126(49)$ & $0.2-19.6(10.3)$ & $1-440(90)$ \\
\hline Fire fatality & 23 & $0.3-10.5(1.7)$ & $130-700(226)$ & $14-216(26)$ & $2.3-39.0(13.1)$ & $4-708(121)$ \\
\hline $\mathrm{CO}-\mathrm{Hb}<30 \%$ & 12 & $0.3-5.1(1.5)$ & $130-700(239.5)$ & $15-37(19)$ & $3.0-39.0(14.5)$ & 4-441 (131) \\
\hline $\mathrm{CO}-\mathrm{Hb} 30-60 \%$ & 6 & $1.1-3.9(1.8)$ & $178-358(201)$ & $14-216(15)$ & $2.3-20.6(9.6)$ & $32-708(228.5)$ \\
\hline $\mathrm{CO}-\mathrm{Hb}>60 \%$ & 5 & $0.3-10.5(3.1)$ & $182-287(229)$ & $15-48(39)$ & $10.2-27.3(23.8)$ & $34-680(110)$ \\
\hline Drowning & 11 & $0.8-4.5(1.8)$ & $68-1270(275)$ & $28-147(45)$ & $3.4-33.0(14.4)$ & $1-693(273)$ \\
\hline Acute cardiac death & 12 & $0.7-8.7(2.9)$ & $188-1418$ (492.5) & $30-654(92)$ & $4.8-72.5(10.9)$ & $1-546(248.5)$ \\
\hline Total & 94 & $0.3-26.4(2.8)$ & $68-3550(299.5)$ & $14-654(43)$ & $0.2-72.5(12.7)$ & $1-830(217.5)$ \\
\hline
\end{tabular}

$\mathrm{CO}-\mathrm{Hb}$ carbon monoxide hemoglobin 

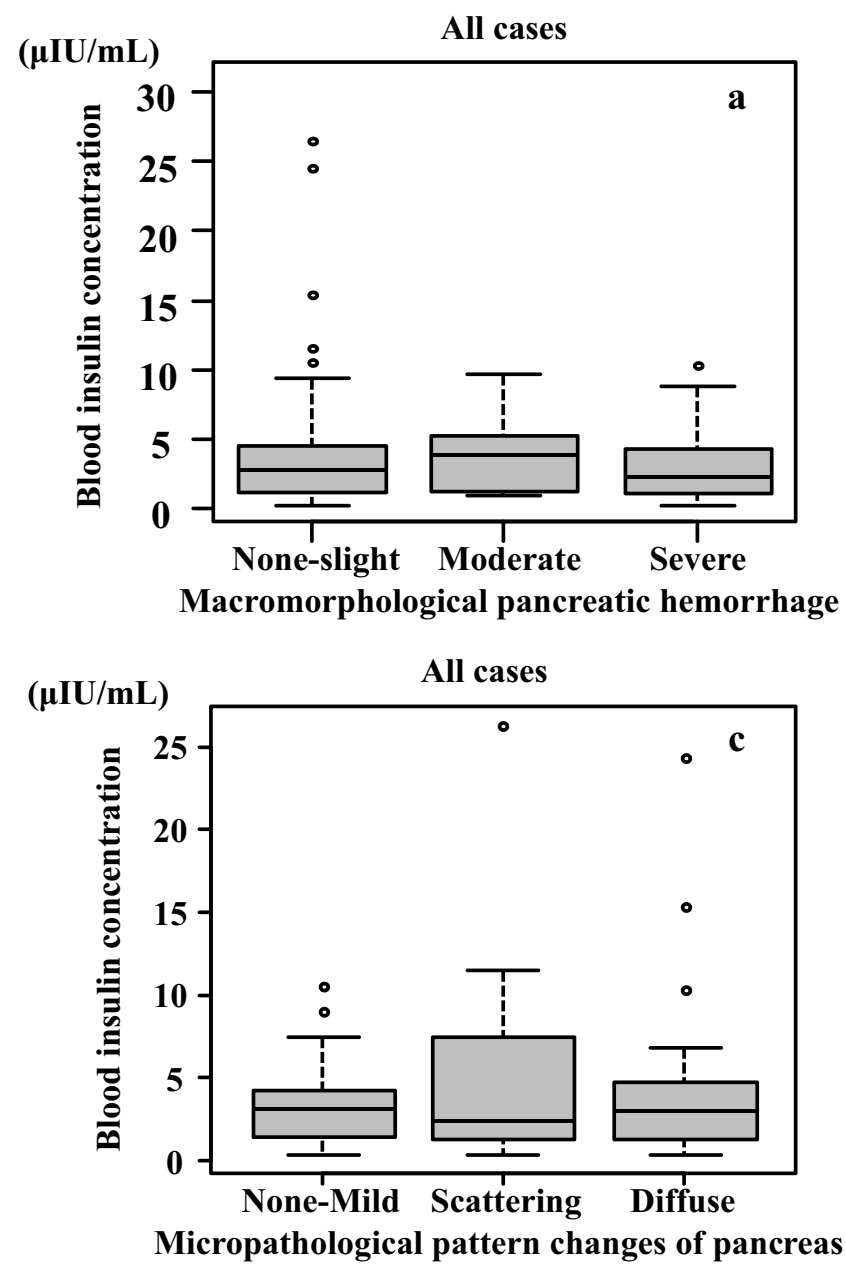

Fig. 7 Comparison between macromorphological pancreatic hemorrhage levels and blood insulin levels in cases with pancreatic subcapsular/interstitial hemorrhage. There was no relationship observed between the hemorrhage levels and blood insulin levels (a: all cases, b: asphyxia cases) $(p>0.05)$. Histological comparison between

\section{Discussion}

We used three methods to evaluate pancreatic morphological changes under systemic hypoxia conditions. First, we examined the ratio and degree of the macroscopic subcapsular/ interstitial hemorrhage. Second, we evaluated the pattern of the changes in the histologic tissue. Third, we investigated the insulin and glucagon-positive ratio in the islet cells as it related to each cause of death. Results showed that subcapsular/interstitial hemorrhage was observed as a macroscopic change in the pancreas after death from systemic hypoxia, which is commonly known as asphyxia. Hypoxic conditions have been shown to cause injuries to organ tissues and the vascular system $[10,44]$. Eguchi et al. showed that the human blood vessel endothelium in vitro was cleared with the aid of Heat shock protein (Hsp) [45]. One of the common functions of Hsp is the inhibition of apoptosis. Thus, during
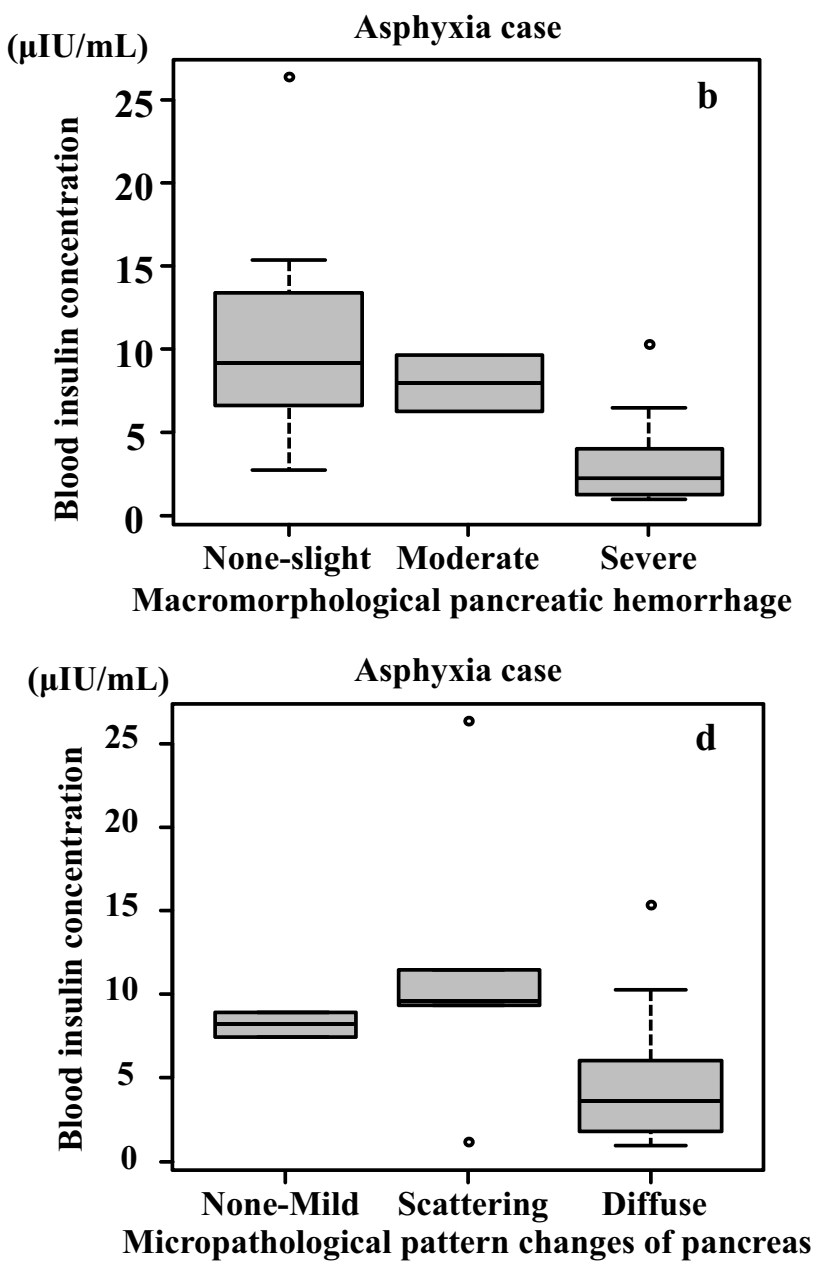

the pattern changes in the tissue and blood insulin level in the pancreas. There was no relationship observed between the tissue pattern changes and the blood insulin level in the cases (c: all cases, d: asphyxia cases) $(p>0.05)$

the subcapsular/interstitial hemorrhage of the pancreas, the release of Hsp during hypoxia could potentially influence the changes that occur. It has also been reported that various structural proteins are damaged during conditions of hypoxia and needs to be taken into consideration [42,46]. Additional work needs to be done to the mechanism of subcapsular/ interstitial hemorrhage of the pancreas.

Based on these findings, it is highly likely that the pancreatic subcapsular/interstitial hemorrhage that was observed in the present study was the consequence of the hypoxia influence. Severe hemorrhage was more frequently observed in cases of death from asphyxia than in cases of death due to drowning. The pancreatic subcapsular/interstitial hemorrhage findings observed in cases of death due to drowning suggest that drowning involves systemic hypoxia. Other factors, such as alveolar injury, have also been reported to be integrally involved in the process of death $[47,48]$. 

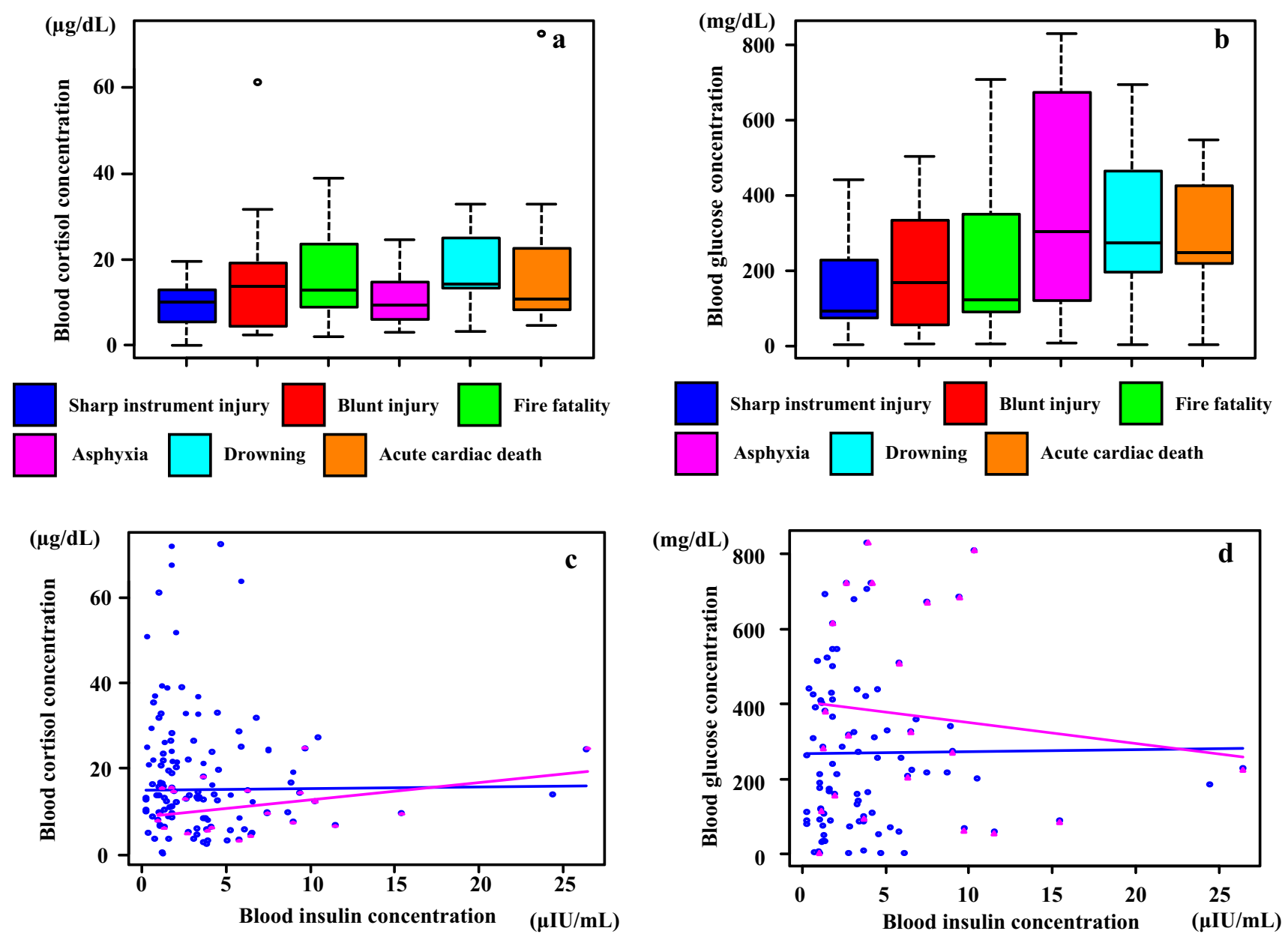

Fig. 8 Blood cortisol (a) and glucose (b) concentrations according to the cause of death in autopsy cases. There was no relationship observed between the cortisol concentrations and causes of death $(p>0.05)$. Evaluation of the correlation between the blood corti-

sol (c), glucose (d), and the blood insulin concentrations revealed that there was no relationship between these groups [blue lines and circles: all cases $(p>0.05)$; red lines and triangles: asphyxia cases $(p>0.05)]$

Pancreatic hemorrhage has been observed in approximately $40 \%$ of acute cardiac deaths. This finding may be attributable to systemic hypoxic injuries that result from circulatory failure due to cardiovascular injury [6]. In our pathohistological examination, tissue changes were frequently observed in asphyxia and acute cardiac deaths, and severe tissue changes were particularly observed more frequently in asphyxia. Immunostaining of the islets of Langerhans in the pancreas demonstrated that there was no difference in the percentages of the insulin- and glucagon-positive cells. The blood biochemistry tests revealed glucagon levels did not differ between the various causes of death, and the blood insulin levels in the asphyxia group were higher than those observed in all other groups. While these results suggest that hypoxic conditions can cause injuries to blood capillaries in the pancreas, insulin leakage does not appear to be attributable to cell disintegration. Pancreatic hemorrhage or micromorphological changes were not correlated with the blood insulin

levels. In contrast, no differences were observed between the causes of death in relation to the secretion of pancreatic amylase from the pancreatic exocrine gland. All pancreatic amylase levels were within the clinical standard range. These results revealed that the endocrine gland was stimulated though the external secretion organization of the pancreas and was not affected by the acute hypoxia condition.

Previous research found that the mechanism underlying the increased blood insulin levels during hypoxic conditions could be explained by hyperglycemia induced by elevated cortisol levels [49]. Our previous studies have shown that asphyxia, a hypoxic condition does not induce any noticeable response in the blood cortisol level. We did find that exposure to cold induces a response in blood cortisol levels [50]. In this study blood cortisol levels did not differ markedly between the different causes of death.

We found blood glucose levels to be varied, but our results showed that there was no difference in the blood 

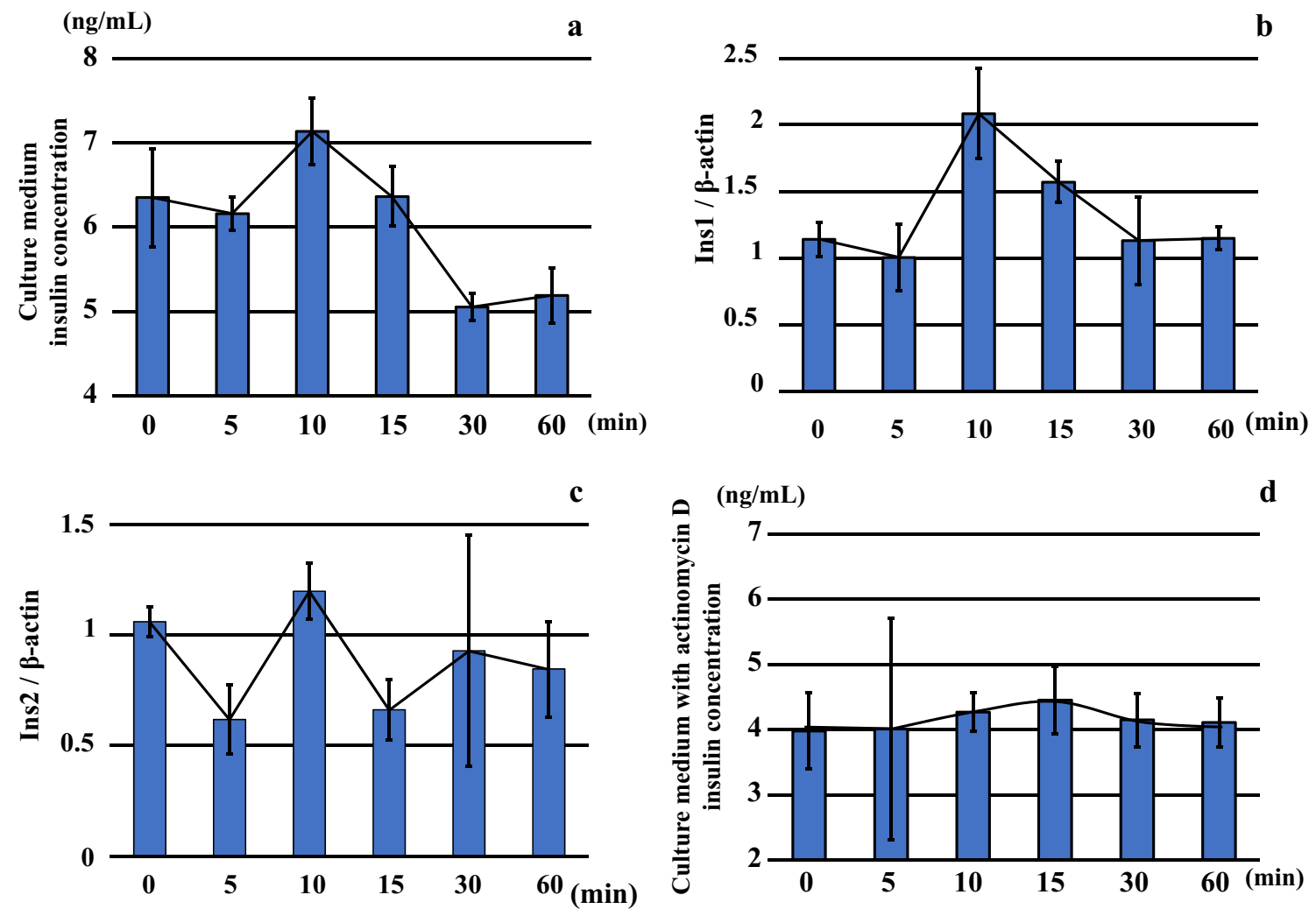

Fig. 9 Insulin concentrations (a) and insulin mRNA levels, including Ins1 (b) and Ins2 (c), in the conditioned medium BRIN-BD11 cultured under hypoxic conditions $\left(\mathrm{O}_{2} 5 \%\right)$. Insulin levels were highest after 10 min of incubation under hypoxic conditions. However, insulin levels gradually decreased after $15 \mathrm{~min}$. With regard to insulin mRNA expressions, Ins1 expression increased after incubation for 10 min under hypoxic conditions. Ins 2 expression did not exhibit

any remarkable change under the hypoxic conditions as compared to that observed for Ins1 mRNA expression. Furthermore, after adding actinomycin D to the BRIN-BD11 cells, there was inhibition of the reproduction and transcription from the DNA. Results showed that the insulin exhibited low levels as compared to the actinomycin D non-addition experiment (d)

glucose levels observed in the deaths due to different causes. No correlation between blood glucose or cortisol levels and insulin levels was found. These results suggest that there is a direct effect of hypoxia on insulin secretion.

Based on these previous findings, we performed an experiment using Langerhans cells from the rat pancreas to observe changes in insulin mRNA and protein levels related to insulin secretion during hypoxic conditions. We found that insulin mRNA reached its peak in approximately $10 \mathrm{~min}$ during hypoxic conditions. Insulin protein levels also peaked around 10 min under hypoxic conditions and then decreased. Another research study reported that insulin increased after 2-3 min of hypoxia [49], which suggests that the pancreatic tissue is sensitive to acute conditions of hypoxia.

In rat islets the conversion of proinsulin to insulin begins about 30 min after ribosomal synthesis of preproinsulin and resembles first-order reaction kinetics with half-times of approximately 30-60 min [51]. However, the present cell culture experimental data, confirmed there were increases of both Ins1 mRNA and insulin during the first $10 \mathrm{~min}$ of

hypoxia exposure. Furthermore, we found that the addition of actinomycin D starting at $24 \mathrm{~h}$ after the initiation of the culture led to no further changes in the insulin secretion quantity at each of the time points. These results suggest that the insulin secretion system is influenced by conditions of hypoxia. As the addition of actinomycin $\mathrm{D}$ in the cultured cells during conditions of hypoxia resulted in small changes in the HIF $1 \alpha$ and VEFG.

The results of the hypoxia experiment with the pancreatic endocrine gland using BRIN-BD11 demonstrated that the HIF $1 \alpha$ and VEGF increases occurred after the time insulin secretion increase was noted during hypoxic conditions. This suggests that the secretion of insulin during conditions of hypoxia was not affected by HIF1 $\alpha$.

Morphological changes in cultured pancreatic internal secretion cells during hypoxia were not noticeable for up to $10 \mathrm{~min}$. Mitochondrial swelling and disintegration of nuclear structure only becoming noticeable at $15 \mathrm{~min}$. Results of the electron microscopic examination also revealed that the activity of insulin secretion genes was not altered until 
Table 4 Insulin, HIF1 $\alpha$, and VEGF in BRIN-BD11 with and without actinomycin D, and mRNA insulin level in BRIN-BD11

\begin{tabular}{|c|c|c|c|c|c|c|c|c|}
\hline \multirow{2}{*}{$\begin{array}{l}\text { Cultured time } \\
\text { under hypoxia } \\
(\min )\end{array}$} & \multicolumn{5}{|c|}{ Pancreatic endocrine cell culture (BRIN-BD11) } & \multicolumn{3}{|c|}{$\begin{array}{l}\text { Pancreatic endocrine cell culture (BRIN-BD11) } \\
\text { with actinomycin D }\end{array}$} \\
\hline & $\begin{array}{l}\text { Insulin } \\
(\mathrm{ng} / \mathrm{mL})\end{array}$ & Ins $1 / \beta$-actin & Ins $2 / \beta$-actin & $\begin{array}{l}\text { HIF1 } \alpha(\mathrm{ng} / \\
\text { mL) } \\
(\text { median) }\end{array}$ & $\begin{array}{l}\text { VEGF (ng/ } \\
\text { mL) } \\
\text { (median) }\end{array}$ & $\begin{array}{l}\text { Insulin (ng/ } \\
\text { mL) } \\
\text { (median) }\end{array}$ & $\begin{array}{l}\text { HIF1 } \alpha(\mathrm{ng} / \\
\text { mL) } \\
\text { (median) }\end{array}$ & $\begin{array}{l}\text { VEGF }(\mathrm{pg} / \mathrm{mL}) \\
\text { (median) }\end{array}$ \\
\hline 0 & $\begin{array}{l}5.58-6.99 \\
(6.49)\end{array}$ & $\begin{array}{l}1.00-1.31 \\
(1.11)\end{array}$ & $\begin{array}{l}1.00-1.15 \\
(1.02)\end{array}$ & $\begin{array}{l}0.48-3.10 \\
\quad(1.74)\end{array}$ & $\begin{array}{c}1017.0- \\
1250.0 \\
(1209)\end{array}$ & $\begin{array}{l}3.12-4.56 \\
(4.35)\end{array}$ & $\begin{array}{l}1.07-5.11 \\
(3.20)\end{array}$ & $\begin{array}{l}367.4-485.9 \\
\quad(439.2)\end{array}$ \\
\hline 5 & $\begin{array}{l}5.89-6.36 \\
(6.23)\end{array}$ & $\begin{array}{l}0.72-1.33 \\
(0.97)\end{array}$ & $\begin{array}{l}0.50-0.84 \\
(0.52)\end{array}$ & $\begin{array}{l}0.52-4.19 \\
(2.32)\end{array}$ & $\begin{array}{l}957.7-1190.0 \\
(1014)\end{array}$ & $\begin{array}{l}2.40-7.10 \\
(3.12)\end{array}$ & $\begin{array}{l}0.68-5.68 \\
(3.08)\end{array}$ & $\begin{array}{c}368.2-484.3 \\
(428.1)\end{array}$ \\
\hline 10 & $\begin{array}{l}6.58-7.46 \\
(7.36)\end{array}$ & $\begin{array}{l}1.78-2.55 \\
(1.92)\end{array}$ & $\begin{array}{l}1.02-1.30 \\
(1.27)\end{array}$ & $\begin{array}{l}0.59-6.59 \\
(1.92)\end{array}$ & $\begin{array}{l}950.0-1159.0 \\
(1131)\end{array}$ & $\begin{array}{l}3.70-4.58 \\
(4.33)\end{array}$ & $\begin{array}{l}2.46-5.37 \\
(2.63)\end{array}$ & $\begin{array}{c}396.8-478.9 \\
(432.5)\end{array}$ \\
\hline 15 & $\begin{array}{l}5.89-6.73 \\
\quad(6.47)\end{array}$ & $\begin{array}{l}1.39-1.77 \\
(1.55)\end{array}$ & $\begin{array}{l}0.47-0.76 \\
(0.75)\end{array}$ & $\begin{array}{l}0.45-5.66 \\
(2.92)\end{array}$ & $\begin{array}{c}1247.0- \\
1694.0 \\
(1336)\end{array}$ & $\begin{array}{l}3.97-5.43 \\
(4.22)\end{array}$ & $\begin{array}{l}0.83-8.54 \\
(2.59)\end{array}$ & $\begin{array}{c}391.1-552.0 \\
(413.9)\end{array}$ \\
\hline 30 & $\begin{array}{l}4.86-5.25 \\
(5.06)\end{array}$ & $\begin{array}{l}0.89-1.59 \\
(0.91)\end{array}$ & $\begin{array}{l}0.31-1.59 \\
(0.88)\end{array}$ & $\begin{array}{l}2.97-7.33 \\
(4.39)\end{array}$ & $\begin{array}{c}1138.0- \\
1684.0 \\
(1401)\end{array}$ & $\begin{array}{l}3.50-4.72 \\
(4.22)\end{array}$ & $\begin{array}{l}1.45-5.42 \\
(2.74)\end{array}$ & $\begin{array}{c}391.9-540.7 \\
(438.4)\end{array}$ \\
\hline 60 & $\begin{array}{l}4.73-5.45 \\
(5.39)\end{array}$ & $\begin{array}{l}1.06-1.27 \\
(1.12)\end{array}$ & $\begin{array}{l}0.55-1.07 \\
(0.92)\end{array}$ & $\begin{array}{l}1.19-4.46 \\
(2.47)\end{array}$ & $\begin{array}{c}1062.0- \\
1331.0 \\
(1268)\end{array}$ & $\begin{array}{c}3.69-4.72 \\
(4.07)\end{array}$ & $\begin{array}{l}0.65-7.63 \\
(4.32)\end{array}$ & $\begin{array}{c}376.7-501.4 \\
(449.8)\end{array}$ \\
\hline
\end{tabular}

a

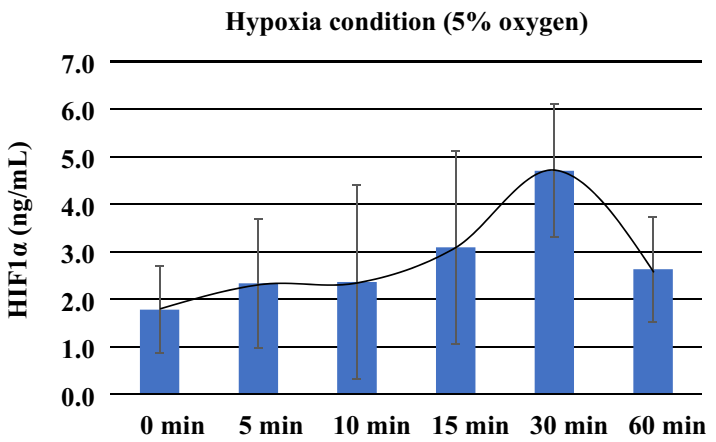

c

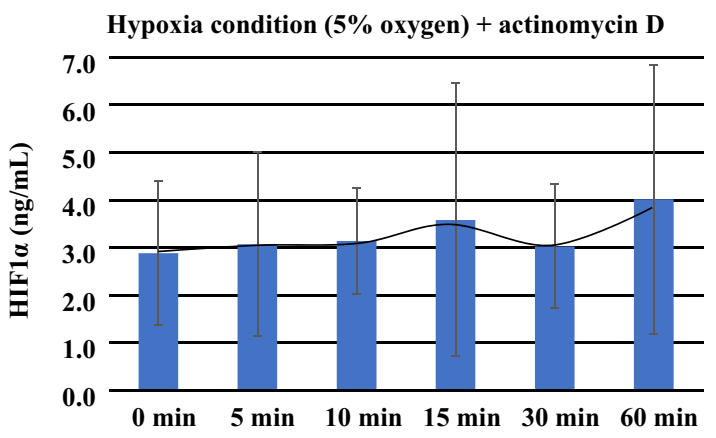

Fig. 10 Graph shows the HIF1 $\alpha$ and VEGF concentrations in the conditioned medium BRIN-BD11 that was cultured under hypoxic conditions. a Levels of HIF1 $\alpha$ and VEGF, which were used as the hypoxia control markers for cellular function during the hypoxic conditions in the BRIN-BD11 cells, increased starting from $30 \mathrm{~min}$ in HIF1 $\alpha$. b The graph shows the VEGF concentrations from $15 \mathrm{~min}$ to $60 \mathrm{~min}$,

\section{b}

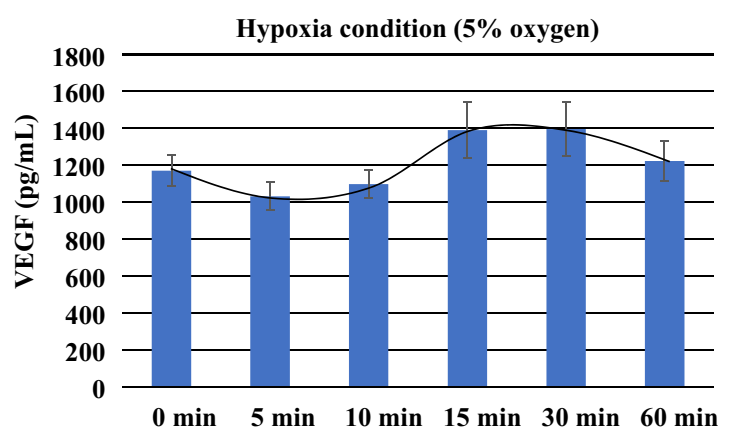

d

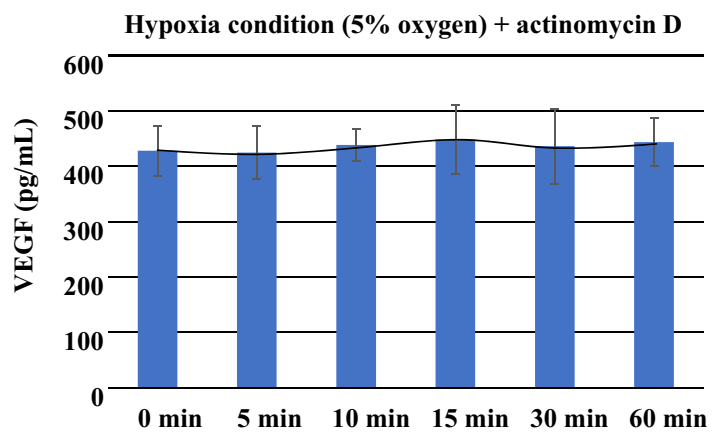

with the maximum reached from $15 \mathrm{~min}$ to $30 \mathrm{~min}$. The figure also shows the HIF1 $\alpha$ (c) and VEGF (d) levels after the addition of actinomycin $\mathrm{D}$ during the conditions of hypoxia. The addition of actinomycin $\mathrm{D}$ in the cultured cells during the hypoxia, led to smaller changes in both the HIF1 $\alpha$ and VEGF 
$(\mathbf{I U} / \mathbf{L})$

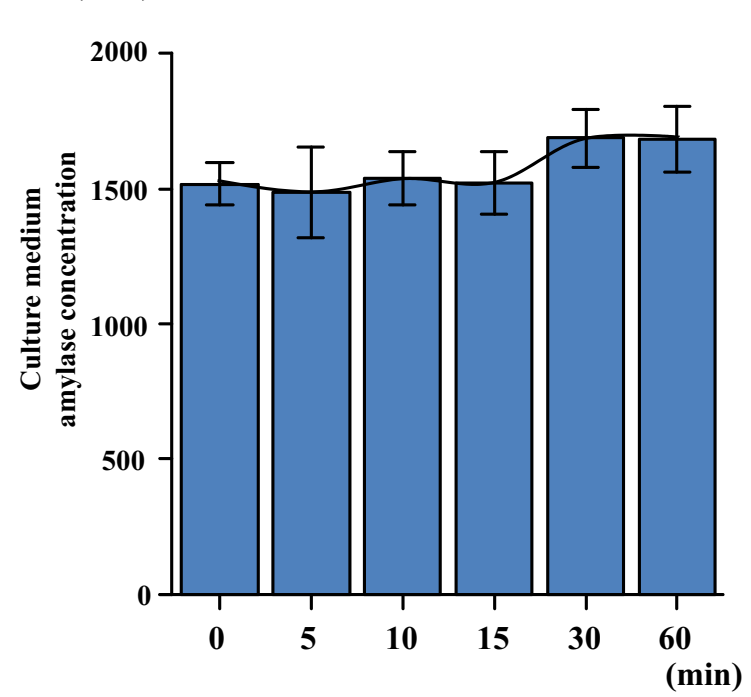

b

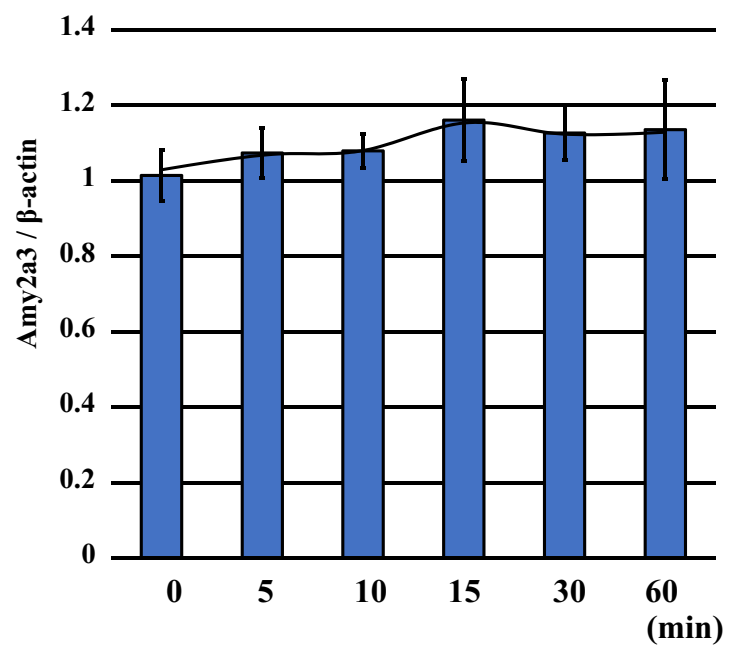

Fig. 11 AR42J cells exhibited no increased amylase levels (a) or amylase mRNA (Amy2a3) levels (b) in the culture medium following incubation for 0-60 min under hypoxic conditions $\left(\mathrm{O}_{2} 5 \%\right)$ at each of the respective time points

around 10 min during hypoxic conditions. In contrast, there were no remarkable morphological changes in the organelles of the external secretion cell line (AR42J) as compared to the internal secretion cell line (BRIN-BD11) during conditions of hypoxia. No significant differences were observed during hypoxia for either the mRNA or amylase protein levels in the cultured cells. Hormone secretion and organelle changes during hypoxia were more pronounced in the pancreatic endocrine gland than the exocrine gland. Overall, these findings suggest that the insulin changes noted during conditions of hypoxia were due to a special reaction of the pancreatic endocrine system.

In autopsy cases, it is important that blood is collected from the vascular supply area central to the pathology [52]. This suggests that the portal vein would be the preferred blood collection site for studies of the pancreas. We opted to use blood collected from the right heart chamber

Table 5 Amylase concentrations and mRNA levels in the conditioned medium AR42J cultured under hypoxic conditions

\begin{tabular}{|c|c|c|}
\hline \multirow{2}{*}{$\begin{array}{l}\text { Cultured time } \\
\text { under hypoxia } \\
(\mathrm{min})\end{array}$} & \multicolumn{2}{|c|}{ Pancreatic acinar cell culture (AR42J) } \\
\hline & $\begin{array}{l}\text { Amylase (IU/L) } \\
\text { (median) }\end{array}$ & Amy $2 \mathrm{a} 3 / \beta$-actin \\
\hline 0 & $1431-1635(1516.5)$ & $1.00 / 1.13 / 1.01 / 1.02 / 0.90 / 1.00$ \\
\hline 5 & $1200-1692(1491.0)$ & $1.01 / 1.01 / 1.00 / 1.08 / 1.17 / 1.14$ \\
\hline 10 & $1407-1677(1552.5)$ & $1.07 / 1.03 / 1.15 / 1.01 / 1.07 / 1.11$ \\
\hline 15 & $1422-1752(1488.0)$ & $1.09 / 1.02 / 1.18 / 1.13 / 1.14 / 1.37$ \\
\hline 30 & $1578-1887(1656.0)$ & $1.15 / 1.13 / 1.05 / 1.25 / 1.03 / 1.12$ \\
\hline 60 & $1563-1902(1674.0)$ & $1.03 / 1.20 / 1.16 / 1.16 / 1.33 / 0.91$ \\
\hline
\end{tabular}

because there is an insufficient amount of available via the portal vein. Our previous studies on amylase related to the pancreas were also conducted using blood predominantly collected from the right heart chambers [10].

Pancreatic cells cultured in 5\% $\mathrm{O}_{2}$ were also used as a model of a hypoxic environment. The effects on hormone secretion were not clearly observed in the adrenocortical cells that were cultured under these conditions. When adrenocortical cells were cultured under a $1 \% \mathrm{O}_{2}$ hypoxic environment, the corticosterone level reached its peak at $120 \mathrm{~min}$. However, this finding does not support that insulin secretion under hypoxic conditions is clearly affected by corticosterone secretion. An independent experiment that we conducted to examine pancreatic cells under hypoxia, showed that hypoxia itself stimulated Langerhans cells in the pancreas to induce secrete insulin. The results from our present study demonstrate that increases of insulin related to the hypoxia stress are not dependent on either the cortisol or glucose levels.

\section{Conclusion}

Current experimental results suggest that acute systemic hypoxic conditions can directly affect the mechanisms involved in pancreatic insulin secretion.

Funding The authors received no specific funding for this work. 


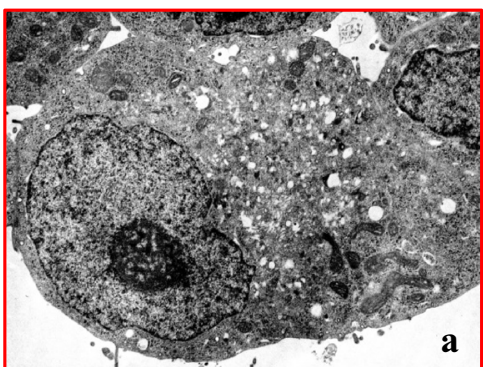

0 min

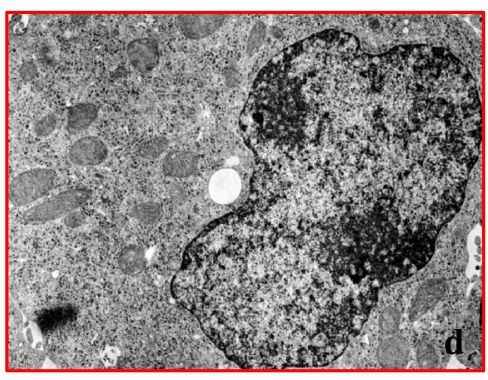

$15 \mathrm{~min}$

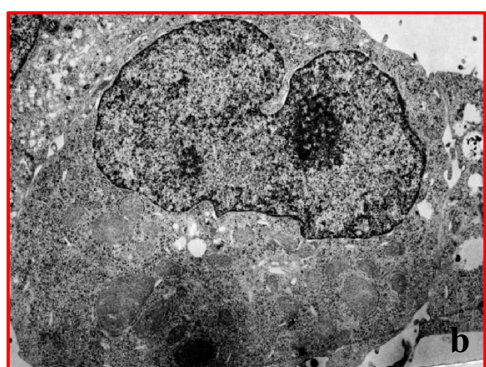

$5 \mathrm{~min}$

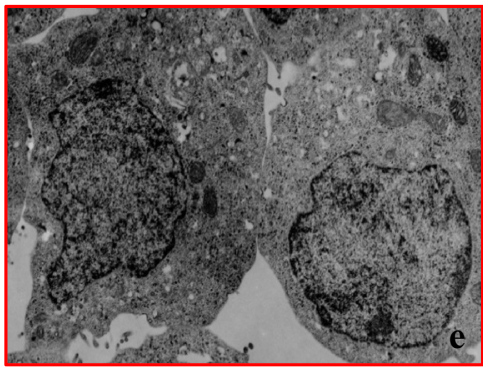

$30 \mathrm{~min}$

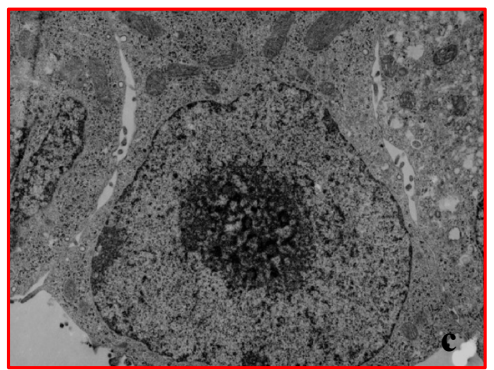

$10 \mathrm{~min}$

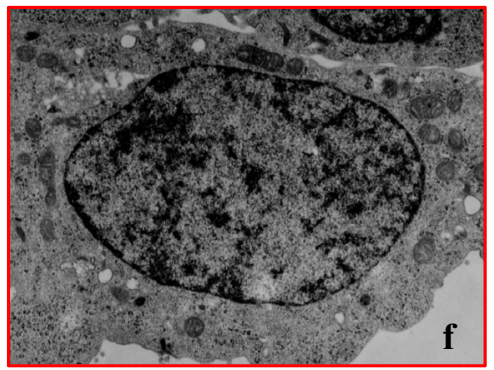

$60 \mathrm{~min}$
Fig. 12 Transmission electron microscopy images of the BRIN-BD (rat islets) cell culture model during conditions of hypoxia $\left(\mathrm{O}_{2} 5 \%\right)$. Cell structure remained normal until approximately $10 \mathrm{~min}$ after the hypoxia. However, mitochondrial swelling and nuclear structure collapse findings became apparent around $15 \mathrm{~min}$ after the hypoxia (hypoxic condition period: a $0 \mathrm{~min}, \mathbf{b} 5 \mathrm{~min}, \mathbf{c} 10 \mathrm{~min}, \mathbf{d} 15 \mathrm{~min}, \mathbf{e}$ $30 \mathrm{~min}$, and $\mathbf{f} 60 \mathrm{~min}$ )

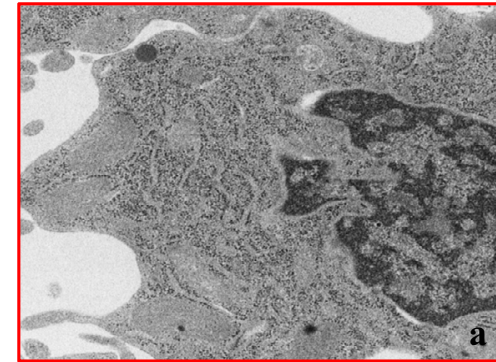

0 min

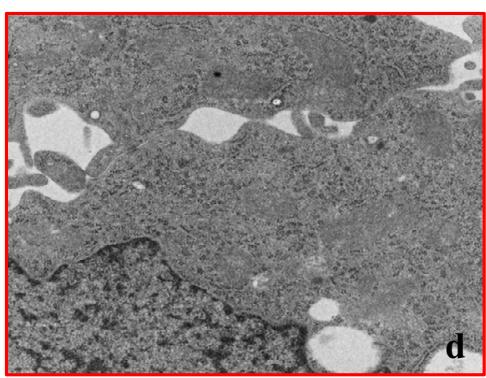

$15 \mathrm{~min}$

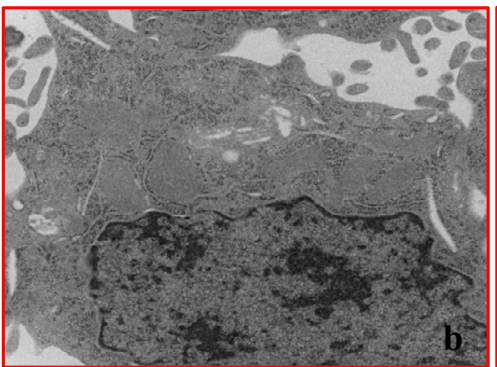

5 min

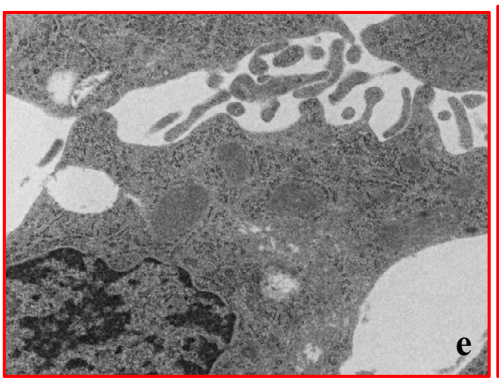

$30 \mathrm{~min}$

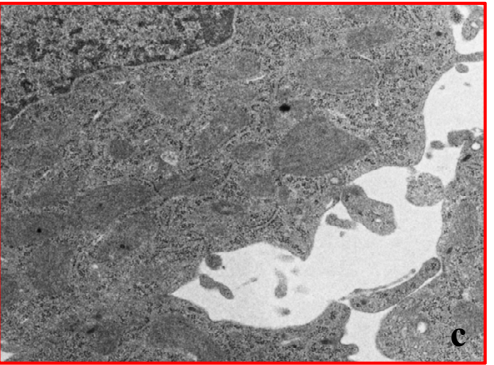

$10 \mathrm{~min}$

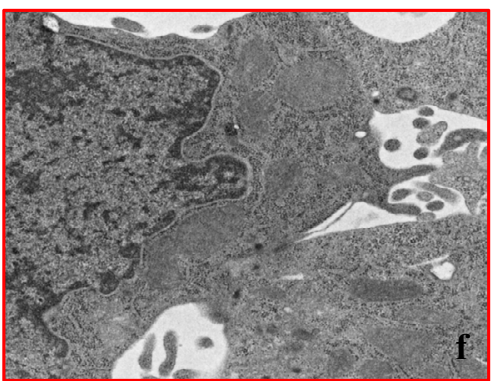

$60 \mathrm{~min}$
Fig. 13 Transmission electron microscopy images of the AR42J (rat acinar cells) cell culture model during conditions of hypoxia $\left(\mathrm{O}_{2} 5 \%\right)$. In the AR42J cells, there were no changes in the cell organelles as the hypoxia progressed as compared to the pancreatic internal secretion cells (BRIN-BD11), with the exception for mitochondrial edema $(\mathbf{a}-\mathbf{f})$ 

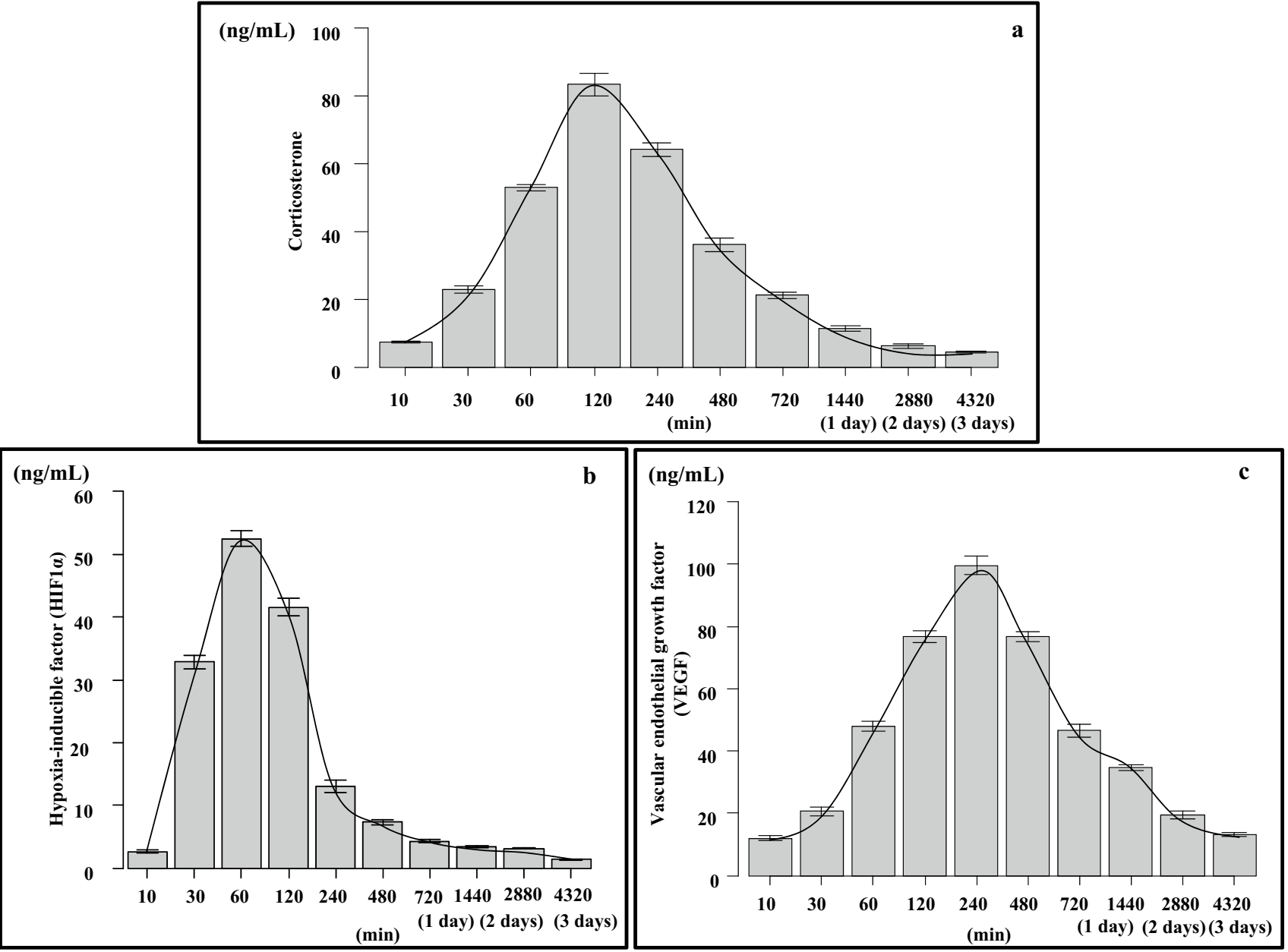

Fig. 14 Corticosterone (a), HIF1 $\alpha$ (b), and VEGF (c) concentration levels were highest after $60 \mathrm{~min}$, while the VEGF concentration tions in the conditioned medium Y-1 cultured under hypoxic conditions $\left(\mathrm{O}_{2} 1 \%\right)$. Corticosterone concentration levels were highest after 120 min of incubation under hypoxic conditions. HIF1 $\alpha$ concentralevels were highest after $240 \mathrm{~min}$ of incubation under hypoxic conditions

Table 6 Adrenal cortex cell (Y-1) culture under hypoxia

\begin{tabular}{rlrr}
\hline $\begin{array}{l}\text { Cultured time under } \\
\text { hypoxia } \\
(\mathrm{min})\end{array}$ & \multicolumn{2}{l}{ Adrenal cortex cell culture (Y-1) } \\
\cline { 2 - 4 } $\begin{array}{l}\text { Corticosterone }(\mathrm{ng} / \mathrm{mL}) \\
\text { (median) }\end{array}$ & $\begin{array}{l}\text { HIF1 } \alpha(\mathrm{ng} / \mathrm{mL}) \\
(\text { median})\end{array}$ & $\begin{array}{l}\text { VEGF }(\mathrm{ng} / \mathrm{mL}) \\
\text { (median) }\end{array}$ \\
\hline 0 & - & - & - \\
5 & - & - & - \\
10 & $7.1-7.9(7.4)$ & $2.2-3.1(2.6)$ & $10.8-12.8(12.3)$ \\
15 & - & - & - \\
30 & $21.5-24.6(22.8)$ & $31.6-34.4(32.6)$ & $18.5-22.7(20.6)$ \\
60 & $51.6-54.8(52.6)$ & $50.6-54.4(52.8)$ & $45.2-49.5(48.3)$ \\
120 & $79.7-88.6(82.6)$ & $39.4-43.6(41.8)$ & $74.2-79.6(76.2)$ \\
240 & $60.7-66.7(64.3)$ & $11.8-14.3(12.8)$ & $96.7-105.2(98.5)$ \\
480 & $33.5-38.4(35.5)$ & $6.8-8.1(7.2)$ & $74.6-78.7(77.1)$ \\
720 & $19.7-22.4(21.3)$ & $3.9-4.6(4.2)$ & $44.2-48(46.4)$ \\
1440 & $10.3-12.6(11.2)$ & $3.2-3.6(3.5)$ & $33.7-36.3(34.4)$ \\
2880 & $5.1-7.1(6.6)$ & $3.0-3.2(3.2)$ & $17.8-21.2(19.4)$ \\
4320 & $4.1-5.0(4.3)$ & $1.2-1.5(1.3)$ & $12.3-14.1(13.5)$ \\
\hline
\end{tabular}




\section{Compliance with ethical standards}

Conflict of interest The authors declare they have no conflict of interest.

Statement of human rights All procedures performed in studies involving human participants were in accordance with the ethical standards of the institutional and/or national research committee and with the 1964 Helsinki declaration and its later amendments or comparable ethical standards. The independent Ethics Committee at Osaka City University Graduate School of Medicine approved this study (Authorization No. 2001). According to the Independent Ethics Committee of the Osaka City University Graduate School of Medicine, informed consent from opt-out for the autopsy data analysis was approved.

Open Access This article is licensed under a Creative Commons Attribution 4.0 International License, which permits use, sharing, adaptation, distribution and reproduction in any medium or format, as long as you give appropriate credit to the original author(s) and the source, provide a link to the Creative Commons licence, and indicate if changes were made. The images or other third party material in this article are included in the article's Creative Commons licence, unless indicated otherwise in a credit line to the material. If material is not included in the article's Creative Commons licence and your intended use is not permitted by statutory regulation or exceeds the permitted use, you will need to obtain permission directly from the copyright holder. To view a copy of this licence, visit http://creativecommons.org/licenses/by/4.0/.

\section{References}

1. Kimura H, Ota H, Kimura Y, Takasawa S. Effects of intermittent hypoxia on pulmonary vascular and systemic diseases. Int $\mathbf{J}$ Environ Res Public Health. 2019;16:3101.

2. Prisby RD. Mechanical, hormonal and metabolic influences on blood vessels, blood flow and bone. J Endocrinol. 2017;235:R77-100.

3. Xing J, Ying Y, Mao C, et al. Hypoxia induces senescence of bone marrow mesenchymal stem cells via altered gut microbiota. Nat Commun. 2018;9:2020.

4. Fisher DA. Endocrinology of fatal development. In: Kronenberg HM, Melmed S, Polonsky KS, Larsen PR, editors. Williams textbook of endocrinology, 11th ed. Philadelphia, PA: Saunders; 2007. p. 755-82.

5. Fink G, Pfaff DW, Levine JE, editors. Handbook of Neuroendocrinology. 1st ed. Cambridge (MA): Academic Press; 2011.

6. Tani N, Ikeda T, Shida A, Aoki Y, Oritani S, Ishikawa T. Postmortem water contents of major organs with regard to the cause of death. J Forensic Leg Med. 2019;65:48-54.

7. Zeng Y, Lv Y, Tao L, et al. G6PC3, ALDOA and CS induction accompanies mir-122 down-regulation in the mechanical asphyxia and can serve as hypoxia biomarkers. Oncotarget. 2016;7:74526-36.

8. Tani N, Ishikawa M, Watanabe M, Ikeda T, Ishikawa T. Thyroidrelated hormones as potential markers of hypoxia/ischemia. Hum Cell. 2020;33:545-58.

9. Tani N, Ikeda T, Watanabe M, Toyomura J, Ohyama A, Ishikawa T. Prolactin selectively transported to cerebrospinal fluid from blood under hypoxic/ischemic conditions. PLoS ONE. 2018;13:e0198673.

10. Michiue T, Ishikawa T, Kawamoto $\mathrm{O}$, et al. Postmortem serum levels of amylase and gamma glutamyl transferase (GGT) as markers of systemic tissue damage in forensic autopsy. Leg Med (Tokyo). 2013;15:79-84.

11. Zhu BL, Ishikawa T, Michiue T, et al. Postmortem cardiac troponin T levels in the blood and pericardial fluid. Part 1. Analysis with special regard to traumatic causes of death. Leg Med (Tokyo). 2006;8:86-93.

12. Greco AV, Crucitti F, Ghirlanda G, et al. Insulin and glucagon concentrations in portal and peripheral veins in patients with hepatic cirrhosis. Diabetologia. 1979;17:23-8.

13. Maneva-Radicheva L, Amatya C, Parker C, et al. Autoimmune diabetes is suppressed by treatment with recombinant human tissue Kallikrein-1. PLoS ONE. 2014;9:e107213.

14. Feng $\mathrm{F}, \mathrm{Hu} \mathrm{P}$, Chen L, et al. Display of human proinsulin on the Bacillus subtilis spore surface for oral administration. Curr Microbiol. 2013;67:1-8.

15. Zheng H, Fu J, Xue P, et al. CNC-bZIP protein Nrf1-dependent regulation of glucose-stimulated insulin secretion. Antioxid Redox Signal. 2015;22:819-31.

16. Vierra NC, Dickerson MT, Jordan KL, et al. TALK-1 reduces delta-cell endoplasmic reticulum and cytoplasmic calcium levels limiting somatostatin secretion. Mol Metab. 2018;9:84-97.

17. Palmiere C, Sabatasso S, Torrent C, Rey F, Werner D, Bardy D. Post-mortem determination of insulin using chemiluminescence enzyme immunoassay: preliminary results. Drug Test Anal. 2015;7:797-803.

18. Zhang X, Sun M, Zheng A, Cao D, Bi Y, Sun J. Preparation and characterization of insulin-loaded bioadhesive PLGA nanoparticles for oral administration. Eur J Pharm Sci. 2012;45:632-8.

19. Bugelli V, Campobasso CP, Angelino A, Focardi M, Pinchi V. CLEIA of humor vitreous in a case of suicidal insulin overdose. Leg Med (Tokyo). 2019;40:22-5.

20. Tong F, Wu R, Huang W, et al. Forensic aspects of homicides by insulin overdose. Forensic Sci Int. 2017;278:9-15.

21. Murata M, Adachi H, Nakade T, Oshima S. Glucagon secretion determined by the RIA method is lower in patients with low left ventricular ejection fraction: the new glass study. Diabetes Res Clin Pract. 2018;144:260-9.

22. Ohneda A, Kobayashi T, Nihei J, Iwasa S, Kondo K. Measurement of glucagon in human plasma by enzyme immunoassay. $\mathrm{J}$ Immunoassay. 1983;4:339-49.

23. Hellman B, Salehi A, Gylfe E, Dansk H, Grapengiesser E. Glucose generates coincident insulin and somatostatin pulses and antisynchronous glucagon pulses from human pancreatic islets. Endocrinology. 2009;150:5334-40.

24. Morishita Y, Iinuma Y, Nakashima N, Majima K, Mizuguchi $\mathrm{K}$, Kawamura Y. Total and pancreatic amylase measured with 2-chloro-4-nitrophenyl-4-o-beta-D-galactopyranosylmaltoside. Clin Chem. 2000;46:928-33.

25. Lutz RA, Flückige J. Kinetic determination of glucose with the GEMSAEC (ENI) centrifugal analyzer by the glucose dehydrogenase reaction, and comparison with two commonly used procedures. Clin Chem. 1975;21:1372-7.

26. Deeg R, Kraemer W, Ziegenhorn J. Kinetic determination of serum glucose by use of the hexokinase/glucose-6-phosphate dehydrogenase method. J Clin Chem Clin Biochem. 1980;18:49-52.

27. Marks V, Lloyd K. Preservation of blood samples for glucose analysis by glucose-oxidase. Clin Chim Acta. 1963;8:326.

28. Benjamin EM. Self-monitoring of blood glucose: the basics. Clin Diabetes. 2002;20:45-7.

29. Weykamp C, John WG, Mosca A. A review of the challenge in measuring hemoglobin A1c. J Diabetes Sci Technol. 2009;3:439-45. 
30. Higgs P, Costa M, Freke A, Papasouliotis K. Measurement of thyroxine and cortisol in canine and feline blood samples using two immunoassay analysers. J Small Anim Pract. 2014;55:153-9.

31. Irvine KL, Burt K, Hill AJ, Shaw S, Papasouliotis K. Initial analytic quality assessment and method comparison of an immunoassay for adrenocorticotropic hormone measurement in equine samples. Vet Clin Pathol. 2016;45:154-63.

32. McClenaghan NH, Barnett CR, O'Harte FP, Swanston-Flatt SK, Ah-Sing E, Flatt PR. Characteristics of BRIN-BG5 and BRINBG7, two novel glucose-responsive insulin-secreting cell lines produced by electrofusion. J Endocrinol. 1996;148:409-17.

33. Rosewicz S, Riecken EO, Wiedenmann B. The amphicrine pancreatic cell line AR42J: a model system for combined studies on exocrine and endocrine secretion. Clin Investig. 1992;70:205-9.

34. Dupuy G, Hilaire G, Aubry C. Rapid determination of alpha-amylase activity by use of a new chromogenic substrate. Clin Chem. 1987;33:524-8.

35. Costa ET, Forti FL, Rocha KM, Moraes MS, Armelin HA. Molecular mechanisms of cell cycle control in the mouse Y1 adrenal cell line. Endocr Res. 2004;30:503-9.

36. Yasumura Y, Buonassisi V, Sato G. Clonal analysis of differentiated function in animal cell cultures. I. Possible correlated maintenance of differentiated function and the diploid karyotype. Cancer Res. 1966;26:529-35.

37. Goymann W, Geue D, Schwabl I, et al. Testosterone and corticosterone during the breeding cycle of equatorial and European stonechats (Saxicola torquata axillaris and S. t. rubicola). Horm Behav. 2006;50:779-85.

38. Vázquez-Palacios G, Retana-Márquez S, Bonilla-Jaime H, Velázquez-Moctezuma J. Further definition of the effect of corticosterone on the sleep-wake pattern in the male rat. Pharmacol Biochem Behav. 2001;70:305-10.

39. Yamamoto N, Oyaizu T, Enomoto M, et al. VEGF and bFGF induction by nitric oxide is associated with hyperbaric oxygen-induced angiogenesis and muscle regeneration. Sci Rep. 2020;10:2744.

40. Kang HS, Kwon HY, Kim IK, et al. Intermittent hypoxia exacerbates tumor progression in a mouse model of lung cancer. Sci Rep. 2020;10:1854.

41. Sui Y, Zhang W, Tang T, et al. Insulin-like growth factor-II overexpression accelerates parthenogenetic stem cell differentiation into cardiomyocytes and improves cardiac function after acute myocardial infarction in mice. Stem Cell Res Ther. 2020;11:86.

42. Tani N, Ikeda T, Aoki Y, Shida A, Oritani S, Ishikawa T. Pathophysiological significance of clock genes BMAL1 and PER2 as erythropoietin-controlling factors in acute blood hemorrhage. Hum Cell. 2019;32:275-84.

43. Tanaka F, Tominaga K, Fujikawa Y, et al. Concentration of glial cell line-derived neurotrophic factor positively correlates with symptoms in functional dyspepsia. Dig Dis Sci. 2016;61:3478-85.

44. Bloch K, Vennäng J, Lazard D, Vardi P. Different susceptibility of rat pancreatic alpha and beta cells to hypoxia. Histochem Cell Biol. 2012;137:801-10.

45. Eguchi R, Naitou H, Kunimasa K, et al. Proteomic analysis of hypoxia-induced tube breakdown of an in vitro capillary model composed of HUVECs: potential role of $\mathrm{p} 38$-regulated reduction of HSP27. Proteomics. 2008;8:2897-906.

46. Kaur C, Sivakumar V, Foulds ES. Early response of neurons and glial cells to hypoxia in the retina. Invest Ophthalmol Vis Sci. 2006; 47:1126-41

47. Olshaker JS. Near drowning. Emerg Med Clin North Am. 1992;10:339-50.

48. Zhu BL, Ishida K, Quan L, et al. Pulmonary immunohistochemistry and serum levels of a surfactant-associated protein $\mathrm{A}$ in fatal drowning. Leg Med (Tokyo). 2002;4:1-6.

49. Sawaguchi A, Funao T. Changes in blood glucose and related hormones in experimental asphyxia. Kitasato Med. 1976;6:238-44.

50. Shida A, Ikeda T, Tani N, et al. Cortisol levels after cold exposure are independent of adrenocorticotropic hormone stimulation. PLoS ONE. 2020;15:e0218910.

51. Weiss M, Steiner DF, Philipson LH, et al. Insulin biosynthesis, secretion, structure, and structure-activity relationships. Endotext. 2000-2014; https://pubmed.ncbi.nlm.nih.gov/25905258/

52. Maeda H, Ishikawa T, Michiue T. Forensic biochemistry for functional investigation of death: concept and practical application. Leg Med (Tokyo). 2011;13:55-67.

Publisher's Note Springer Nature remains neutral with regard to jurisdictional claims in published maps and institutional affiliations. 